\title{
A Magyar Királyi Honvédség karhatalmi alkalmazásának szabályozása a HORTHY-korban, császári és királyi előzményekkel
}

A XX. századi világháború két fegyveres szakasza (az 1914-1918-as Nagy Háború és az 1939-1945ös Totális Háború) közötti időszakban a magyar állam nagy jelentőséget tulajdonított a felforgató vagy annak minősített tömegmozgalmak megelőzésének, illetve leverésének. A kiemelt figyelem a magyarországi tanácsköztársaságnak és az azt megelőző őszirózsás forradalomnak volt köszönhető, melyet tovább erősítettek az 1929-1933-as gazdasági válsághoz kötődő - elsősorban baloldali szervezésű - tömegmegmozdulások, illetve az 1940-es bányászsztrájk során a szélsőjobboldal azon törekvése, hogy a gazdasági követelésekkel induló megmozdulásokat politikaivá változtassa. A vizsgált időszakban ennek megfelelően mindvégig elötérben állt a karhatalom alkalmazásának témaköre.

1919 második felétől 1921 derekáig az államhatalom megszilárdítása bizonyos mértékben a magyar haderő és a félkatonai különítmények tevékenységének függvénye is volt. A rendszer konszolidálásának azonban alapvető feltételévé vált egyfelől a katonaság kivonása a direkt polgári rendfenntartásból, másfelől - többek között a külföldi tiltakozások és szankciók hatására - az egyre inkább önállósuló különítmények felszámolása; a túlkapások, vagyis a fehérterror megszüntetése. HORTHY Miklós altengernagy fövezér, majd kormányzó - noha hatalmát nem kis mértékben a paramilitáris szervezeteknek köszönhette — maga állt a folyamat élére és 1921 végére kiiktatta azokat. A keletkezett ürt azonban a katonai vezetés igyekezett betölteni, mégpedig - a rendvédelmi testületek mintegy kiegészítéseként - a Magyar Királyi Honvédséggel. ${ }^{1}$

Az 1930. IX. 1-ei események, az ott tapasztalt tömeg százezres nagysága, valamint az, hogy azt a Magyarországi Szociáldemokrata Párt szervezte, bizonyos értelemben megijesztették a poltikai és a katonai vezetést. Élénken élt még emlékezetükben 1919 márciusa, amikor a szervezett szociáldemokraták nélkül nem lehetett volna kikiáltani a magyarországi tanácsköztársaságot. Jóllehet 1930 őszén nem álltak fenn hasonló körülmények - az ország „csupán” pénzügyi, gazdasági és társadalmi válságba merült, de nem volt adott a vesztes háború utáni sokkhatás, $\mathrm{s}$ nem folyt az ország területeinek szomszédok általi megszállása és integrálása -, a vezetés egy része mégis attól tartott, hogy a történések már magát az államhatalmat veszélyeztetik. Ez utóbbi érzetük ugyan túlzott volt, ám a karhatalom jogi szabályzásának átalakítása mégis e vélelmüket tükrözte.

Az 1940-es évet mintegy végigkísérő sztrájksorozat ugyancsak a karhatalom jogi szabályzásának átgondolására késztette a politikai és a katonai vezetést. Az 1940. IV. 15-17. közötti 5000 fös budapesti építősztrájk egyik következménye 1940. V. 10-én a katonai parancsnokok - úgynevezett hadiüzemi megbízottak - kinevezése volt a hadiüzemmé minősített gazdasági egységekhez. ${ }^{2}$ Ezt az 1939. évi honvédelmi törvény tette lehetővé, ${ }^{3}$ s az intézkedés előkészítése már 1939 szeptembere óta folyamatban volt.

A textilmunkások június végén kirobbant egyhetes munkabeszüntetése érzékenyen érintette az államhatalmat, hiszen azzal egyidejüleg folyt a felvonulás a román határra, amikor is 1918 óta első ízben fordult elő, hogy a Magyar Királyi Honvédség egészét mozgósították. A rögtönítélő bíráskodás korabeli, közkeletü nevén a statárium - 1940. VIII. 9-i kiterjesztése a honvédelem érdekeit sértő cselekményekre tette többek között lehetővé, hogy az 1940. X. 7-én a salgótarjáni szénmedencében kirobbant, mintegy 30000 fősre duzzadt bányászsztrájk letörésére, mint karhatalmat a Magyar Királyi Honvédséget is bevetették. Megjegyzendő azonban, hogy a politikai vezetés ebben az esetben elsősorban a szélsőjobboldal ellen lépett fel, ugyanis az akció hátterében a nyilasmozgalom állt. A kormányzat és a kormányzó az ország német szövetségi rendszerben elfoglalt fegyveres semlegességi státusztát féltette többek között - a szélsőjobboldal térnyerésétől. A fellépés alapját az állami rend megóvása végett szükséges büntetőjogi rendezésekről szóló 1938. évi törvény adta, ${ }^{4}$ amely az állami és társadalmi rend védelméről szóló 1921. évi törvény hatálya alá ${ }^{5}$ sorolta azon mozgalmakat és szervezkedéseket is, amelyek „, . . a a jogrend törvényellenes úton való megváltoztatásának veszélyét rejti magában. " 6

A Magyar Királyi Honvédség felhasználása karhatalmi feladatok ellátására - ezzel együtt mindvégig másodlagos volt, bár sor került konkrét akciókra is, mint az 1923-1924-es bányász- és mozdonyvezetői sztrájk letörésekor, az 1930. IX. 1-ei megmozdulás idején, az 1935. évi választások során, vagy az 1940-es bányászsztrájk alkalmával. A karhatalmi feladatok végrehajtására elsődlegesen az úgynevezett rendészeti alakulatokat (mai terminológiával rendvédelmi szervezeteket) készítették fel, a Magyar Királyi Honvédséget azok kiegészítésére alkalmazták. ${ }^{7}$ A rendészeti alakulatok körét a két 
világháború között a Magyar Királyi Belügyminisztériumhoz tartozó Magyar Királyi Állami Rendőrség (1919. X. 1.), ${ }^{8}$ majd Magyar Királyi Rendőrség (1932. I. 1. $)^{9}$ és a személyi ügyek kivételével a belügyi tárca irányítása alatt álló Magyar Királyi Csendőrség ${ }^{10}$ és a Magyar Királyi Folyamőrség, ${ }^{11}$ továbbá a Magyar Királyi Pénzügyminisztérium felügyelete alatt álló Magyar Királyi Vámőrség (1921. VIII. 25. $)^{12}$ és Magyar Királyi Pénzügyőrség (1867-től), továbbá a regionális és helyi közigazgatási hatóságoknak alárendelt fogházőrség, erdőőrség és mezőőség alkotta. ${ }^{13}$ Az esetek többségében e testületek fellépése elégségesnek bizonyult. ( A polgári magyar állam idöszakában megkülönböztettek katonailag szervezett fegyveres örtestületet és polgári fegyveres örtestületet. A katonailag szervezett fegyveres örtestület tagjai katonai rendfokozatot viseltek, a személyi állomány belsö függelmi viszonyai katonaiak voltak, rájuk a katonák általános jogosultságai és kötelezettségei egyaránt vonatkoztak. Mivel személyükben katonának minősültek, ezért személyi ügyeik intézése a honvédelmi tárca kompetenciájába tartozott, függetlenül attól, hogy az öket foglalkoztató fegyveres örtestület mely tárca, illetve szervezet vezetöjének - föudvarmester, országgyülés elnöke, koronaörök stb. felügyelete alatt állt. Ezzel szemben a polgári fegyveres örtestületek tagjai testületi rangot viselteke rangrendszerek rendfokozatai elnevezésükben és alakjukban is eltértek a katonai rendfokozati rendszer rangjaitól - a személyi állomány belsö függelmi viszonyrendszere pedig nem katonai, hanem hivatalnoki volt. A polgári fegyveres örtestületek személyi állományainak tagjaira a katonákra általában érvényes jogosultságok és kötelezettségek nem vonatkoztak. Mivel személyükben nem minösültek katonának, ezért személyes ügyeik intézése nem a honvédelmi tárca, hanem a testületük felügyeletét ellátó tárca kompetenciájába tarozott. a szerk. $)^{\mathbf{1 4}}$

A kiküldött katonai karhatalmi kötelék parancsnoka mellérendelő viszonyba került az adott feladat végrehajtásába már bevont rendvédelmi alakulatok parancsnokaival. ${ }^{15} \mathrm{Az}$ azokkal való keveredést az utasítások kifejezetten tiltották, sőt még azt is meghatározták, hogy katonák nem használhatók fel a karhatalmi teendőkön túli rendvédelmi jellegü tevékenységek, tehát kifejezetten rendőri-csendőri intézkedések megtételére. Engedményt egyetlen esetben, - a háborús hátország körülményeit és lehetőségeit figyelembe véve - tettek: szükség esetén a katonai karhatalmi alakulatból kikülönített kisebb csoport parancsnokságát átvehette megfelelő rendfokozattal bíró csendőr, de ez a kitétel rendőrökre és más rendvédelmi testületekhez tartozó tisztekre már nem vonatkozott. ${ }^{16}$ Az OsztrákMagyar Monarchia utolsó időszakában szintén mellérendelt viszonyt írtak elő, ám még ez az egyetlen kivétel sem állt fenn: ,... a karhatalom csapatainak parancsnoka nincs felhatalmazva a csendörség felett rendelkezni, éppoly kevéssé áll jogában a csendörtisztnek a karhatalom csapataira befolyást gyakorolni." 17

\section{Katonai karhatalom igénybevétele}

A Magyar Királyi Honvédség karhatalmi igénybevételének eseteit két csoportba sorolták. Az elsőbe tartozott minden olyan igénybevétel, amit előre lehetett látni, illetve tervezni. Ide tartozott a választások lebonyolításának biztosítása, az árvíz és elemi csapások elleni védelem (amire a Honvéd Vezérkar vagy a trianoni békediktátum katonai határozványaiból következő, azok megkerülését célzó rejtés időszakában az annak megfelelő szervezet konkrétan kidolgozott tervekkel rendelkezett), de ide sorolták az olyan tömegmegmozdulásokat is, amelyek kifejlődését elöre lehetett látni. ${ }^{18}$ A második csoportba a váratlanul bekövetkező, szigorúan csak társadalmi jellegủ események tartoztak. ${ }^{19}$

Az első csoportból is kiemelték a választások biztosítását, amellyel a szabályzatokban egy külön paragrafus foglalkozott. ${ }^{20}$ Ebben külön kiemelték, hogy a honvéd karhatalom alkalmazásáról „,a honvédelmi miniszter a belügyminiszterrel egyetértve rendelkezik. "21 $\mathrm{E}$ kitétel nem azért került bele a szabályzatba, mert a választások lebonyolítása eleve belügyi kompetenciába tartozott, hanem a „rendvédelem az első, a honvédség a második” elve okán, ami a későbbiekben, a honvéd karhatalom rendeltetésének leírásakor válik érthetővé. Az elsősorban az 1989 elötti szakirodalomban előfordult állítások (miszerint a választások során az elöre kirendelt karhatalom „segített irányba terelni” a választókat, kire is adják le voksukat) fényében válik érdekessé a szabályzat következő elöírása: „, $A$ karhatalom oly alkalmazása, mely alkalmas volna valamely párt érdekeit elösegiteni vagy hátráltatni, a fegyveres erö hivatásával és tekintélyével össze nem egyeztethetö. " 22

Visszatekintve az időben azt láthatjuk, hogy lényegét tekintve a XX. század elejéhez képest a HORTHY-korban sem a katonai karhatalom fogalma, sem rendeltetése, sem alkalmazásának alapelvrendszere nem módosult az Osztrák-Magyar Monarchia utolsó időszakához képest. Az 1906-os 
karhatalmi szabályzatban ugyancsak egy teljes paragrafus szabályozta a választások biztosítását, ${ }^{23}$ a különbség abban állt, — ami megkülönböztette a két korszak vezetőinek látásmódját — az 1918-1919es történések után és okán az, hogy az 1920-as és 1930-as években jobban tartottak esetleges megmozdulásoktól, mint 1914 elött: az 1906-os szabályzat két és fél, az 1924-es négy oldalban foglalkozott a témával.

Az előzetes egyeztetést 1906-ban is elöírták, ám értelemszerủen nem kettő, hanem több személy között: „a közös hadügyminister a belügyministerrel, illetöleg Horvát-Szlavón-Dalmátország bánjával egyetértöleg fog eljárni, a honvédség elvi kirendelésére vonatkozólag pedig a honvédelmi ministerrel fog megegyezni."24 Vagyis: a magyar belügyminiszter és honvédelmi miniszter nem tárgyalhatott egymással a választások biztosításáról, hanem a Bécsben székelő császári és királyi közös hagyügyminiszter egyeztettet mindkettejükkel (s az 1918 után nem létező horvát bánnal, a Magyar Királysággal társországi státuszban lévő, a Magyar Szent Korona részét képező Horvátországnak az államfó által kinevezett vezetőjével). Az 1906-os szabályzatban az is benne foglaltatott, hogy „,...a politikai hatóságok, különös tekintettel legyenek arra, hogy a tulmérvü karhatalmi kirendelések a katonai érdekekre nézve hátrányosak." ${ }^{25}$ Ugyanez megjelent a Magyar Királyi Honvédség 1924. évi karhatalmi szabályzatában is, noha „gyengített” formában: „A karhatalom részéröl alkalmazott rendszabályok a túlságos szigor mellözésével legyenek egyszerüek...”. ${ }^{26}$

A dualizmuskori és a két világháború közötti karhatalmi szabályzat felépítése is hasonló, még a karhatalmi szabályzatok katonai kódjele sem változott Ferenc József korához képest, minden esetben A15 volt. Megjegyezendő, hogy a katonai karhatalom terén a közös hadseregre (k. u. k. Heer) és a Magyar Királyi Honvédségre azonos, egyazon utasításban összefoglalt szabályzók vonatkoztak. Az viszont határozottan megjelent, hogy „A karhatalmat rendszerint a közös hadsereg (esetleg haditengerészet) adja. A honvédség karhatalmat csak azon esetben állit ki, ha helyben vagy közelben közös hadseregbeli csapatok éppen nem, vagy csak elégtelen számban állnak rendelkezlésre. "27 Elemi csapások esetére ez a megszorítás nem vonatkozott.

Visszatérve a két világháború közötti Magyar Királyság időszakára, mindkét — tehát előre tervezhető vagy váratlanul bekövetkező - esetben szükség volt a polgári közigazgatás igényének benyújtására. Amennyiben elegendő idő állt rendelkezésre, akkor annak írásban kellett történnie. A kérvény a várost/járást, vármegyét megjárva került a belügyminiszterhez, aki átadta azt a honvédelmi miniszternek, az a honvédség föparancsnokságnak, illetve Honvéd Vezérkarnak, ahonnan aztán az intézkedés a katonai területi parancsnokságokon keresztül jutott el az érintett csapatokig. ${ }^{28}$ (Az 1920-as és 1930-as békeévekben a Honvédség Főparancsnoksága, annak megszünte után háború idején a Honvéd Vezérkar volt a tényleges katonai vezető szervezet. A katonai területi parancsnokságok alatt a békeévekben a vegyesdandár-parancsnokságok, a háború alatt a hadtest-parancsnokságokat is felállító honvéd kerület-parancsnokságok értendők: budapesti I., székesfehérvári II., szombathelyi III., pécsi IV., szegedi V., debreceni VI., miskolci VII.; majd a visszacsatolásokat követően 1938-tól kassai VIII. és 1940-től kolozsvári IX. A hadtesteket római, a vegyes dandárokat és a honvéd kerületparancsnokságokat arab hadrendi számmal jelölték.)

Szükséghelyzetben az igénylést szóban (telefonon) is le lehetett adni a legközelebbi honvédségi alakulat parancsnokának, vagy ügyeletes tisztjének. Ekkor is el kellett azonban készíteni az utólagos írásos igénylést. ${ }^{29} \mathrm{Az}$ előre tervezhető eseményeknél - ilyenek voltak például a választások - a szabályzatok nem tették lehetővé az igénylés gyors és közvetlen módját. ${ }^{30}$ Az általános elözetes, szükséghelyezetben utólagos írásbeliséget az 1906-os szabályzat is elöírta. ${ }^{31}$

Részletesen szabályozták azok körét, akiktől az igénylés kiindulhatott. Figyelemre méltó ebből a szempontól az 1923-ban érvénybe lépett karhatalmi szabályzat, ugyanis az abban lefektetett lista 1942ig érvényben maradt, $s$ akkor is csak lényegtelen, inkább bővítő jellegü módosításokat eszközöltek azon. Ez olyannyira részletes volt, hogy például még a múzeumigazgatókat is felsorolták benne. ${ }^{32}$ (I.sz. melléklet) Hasonló volt a jogosultak köre 1914 előtt is. Olyan stallumok nem kerültek átemelésre, amelyek 1918 után már nem léteztek, például a fiumei és a magyar-horvát tengerparti kormányzó. ${ }^{33}$

A helyi és a központi hatóságok tudták, hogy az ország mely területein nagyobb, s hol kevesebb az esélye tömegmozgalmak kialakulásának, átfogó tervek mégsem készültek. A katonai vezetés arra az álláspontra helyezkedett, hogy teljes bizonyossággal nem jelezhető előre az esetleges tömegmozgalmak kialakulásának pontos helye és területi kiterjedése, következésképpen az országos karhatalmi terv 
inkább akadályozná, mint segítené a Magyar Királyi Honvédség hatékony fellépését.

Helyi szinten más volt a helyzet, a rendvédelmi szervezetek és a honvéd alakulatok rendelkeztek helyőrségük területére érvényes karhatalmi tervekkel. Országos karhatalmi terv készítését mindössze két esetre, a választások biztosítására és az árvízvédelemre írták elő az utasítások és szabályzatok. ${ }^{34}$

Az Osztrák-Magyar Monarchia utolsó időszakában csak árvíz esetére írták elő elózetes az tervek kidolgozását, ${ }^{35}$ ami azonban nem zárta ki azt, hogy helyi szinten is készíthettek karhatalmi terveket.

\section{Karhatalmi alkalmazás elrendelése}

Katonai karhatalom alkalmazását alapvetően a területileg érintett honvéd kerület parancsnoka rendelhette el, hirtelen szükséghelyzet esetét kivéve a Honvédség Főparancsnokságának intézkedése alapján. A kerület parancsnok (illetve törzse) határozta meg a karhatalmi feladatba bevonandó erők nagyságát, eloszlását és feladatait. Az egyes alakulatok felé az ő írásos parancsa alapján az állomás-, illetve a helyőrség-parancsnokok intézkedtek. Több kerületet érintő karhatalmi feladatokra a Honvédség Főparancsnoksága fenntartotta magának az intézkedési jogkört. ${ }^{36}$ Alapesetben a kirendelésre 1914 előtt is a területileg érintett katonai területi parancsnok volt jogosult, több kerületet érintő esetben a Magyar Királyság területén (beleértve Horvátországot is, illetve a közös hadsereg alakulatait is) honvédelmi miniszter. ${ }^{37}$

Szükséghelyzetben a legközelebbi állomás- vagy helyörség-parancsnok is elrendelhette a karhatalmi készültséget, sőt adott esetben egy alakulat ügyeletes tisztje is. Az utólagos tájékoztatást azonban ezen esetekre is elöírták. ${ }^{38} 1914$ előtt ilyen lehetőséget csak „elemi csapásoknál való segélynyújtásra” fogalmaztak meg: „A katonai területi parancsnokságok fel vannak hatalmazva, hogy oly esetekben, midön hirtelen beálló veszély elháritásáról van szó . . . a hivatott közigazgatási (rendör) hatóságok megkeresésére . . karhatalmat az elkerülhetetlen szükség tartamára kirendeljenek. Különösen sürgös esetekben . . katonai segélyosztagoknak a helyörségi állomáson vagy annak közeli körletében való alkalmazását a katonai állomás-parancsnokságok (állomás-parancsnokok) is azonnal és önállóan elrendelhetik." ${ }^{39}$ Sőt: azonnali vészhelyzet esetén , a laktanya és helyörségi ügyeletes tiszt . . . is felvan hatalmazva, hogy . . . saját felelösségére karhatalmat kivonultasson. "40 Az utólagos jelentést, a kirendelt alakulat(ok) hovatartozásától függően, ugyancsak elöirták: „Minden ilyen kirendelés a hadügyministernek (honv. ministernek) bejelentendö." 41

Honvéd alakulatok karhatalmi alkalmazását semmilyen szintủ polgári hatóság, vagy közigazgatási szervezet nem rendelhette el. Ha a beállott szükséghelyzet elvágta őket felettes szervzetüktől, illetve minisztériumuktól, és a rendelkezésükre álló rendvédelmi erő kevésnek bizonyult, akkor is csupán kérhettek a legközelebbi honvédségi alakulat parancsnokától. Annak számára viszont elő volt írva a kérés teljesítése, abban az esetben, ha a történteket maga is hasonlóan veszélyesnek ítélte meg mint az öt a beavatkozásra felkérő polgári vezető. Hasonlóan nem rendelhettek el semmit a honvéd csapatok számára a rendvédelmi alakulatok parancsnokai, még akkor sem, ha beosztásuk és rendfokozatuk egyébként arra alkalmassá tették volna őket. Például egy ezredesi rendfokozatban lévő csendőr kerületparancsnok is csak kéréssel fordulhatott a területére eső honvéd zászlóalj alezredesi rangú parancsnokához. ${ }^{42} 1914$ elött is hasonlóan szabályoztak, hiszen katonai karhatalom még elemi csapás esetén, azonnali szükséghelyzetben is a rendőrhatóság megkeresésére volt kirendelhetö. ${ }^{43}$

Amennyiben a polgári közigazgatási szervezeteket müködésükben megbénították, a területileg illetékes vegyesdandár-parancsnoknak, a legközelebb eső állomás- vagy helyőrség-parancsnoknak (vagy azok ügyeletes tisztjének) nem csupán lehetősége, de egyben kötelessége is volt a karhatalmi beavatkozás elrendelése. Kötelesek voltak: „...saját hatáskörükben minden célravezető intézkedést megtenni, amely a mozgalom terjedésének meggátlására és elfojtására a legalkalmasabbnak mutatkozik." ${ }^{44}$ Természetesen a felettes katonai szervezeteknek a történteket és az intézkedéseket azonnal jelenteni kellett, amelyeknek viszont a polgári hatóságokat kellett tájékoztatniuk minderröl. Érdekes, hogy ennek bevezetésére (szabályozására) csak a Magyar Királyi Honvédelmi Minisztérium 1931. II. 3-ai vezetői értekezlete után került sor. ${ }^{45}$

Az egyszer már kirendelt honvéd karhatalom visszavonására az a katonai parancsnok volt jogosult, aki azt kirendelte. Amennyiben a területileg illetékes polgári közigazgatási vezető nem értett egyet a honvéd karhatalom bevonásával (például korainak tartotta azt), az alakulatnak kint kellett maradnia az alkalmazási körzetben és a belügyminiszternek, illetve a honvédelmi miniszternek kellett egyeztetnie a 
visszavonásról, vagy annak elhalasztásáról. ${ }^{46}$ A karhatalmi feladatokra kirendelt katonai erők visszavonását 1914 előtt, a „politikai hatóság”-okkal és a „közigazgatási közeg”-ekkel egyeztetve, a kirendelést elrendelö katonai területi parancsnok, több katonai területre kiterjedő alkalmazás esetén a honvédelmi miniszter rendelhette el. ${ }^{47}$

A honvédelmi tárca 1931. II. 3-ai vezetői értekezlete - nem utolsósorban az 1930. IX. 1-jei budapesti megmozdulások hatására — megvitatta és módosította a Magyar Királyi Honvédség karhatalmi alkalmazásának alapelveit. A vezérkari főnök — hivatalos megnevezésében a rejtés okán ekkor HM VI. csoportfőnök - előterjesztése alapján elfogadott módosítások lényege a felső katonai vezetés szerepének növelése volt, így az egységes vezetés bevezetését, a parancsnoklás témáját a Magyar Királyi Honvédség főparancsnokára bízta és értelmezhetővé tette, hogy a föparancsnoknak alárendelték a polgári hatóságok képviselőit. Ez a szabályozás elviekben megvalósíthatóbbá tette egy katonai diktatúra adott esetben történő bevezetésének lehetőségét is. A döntéssorozatban szokatlanul erős volt a miniszterelnök szerepe, akinek döntéseit kiemelték a minisztertanács kereteiből, noha a február-márciusi koronatanácson az államfó és a honvédelmi miniszter is a módosítások irányába ható beszédeket mondott. ${ }^{48}$

\section{A karhatalom egységes vezetése}

A kiküldött katonai karhatalmi alakulatot a „rangidős” polgári közigazgatási vezetőhöz utalták. Ö volt köteles gondoskodni a katonák elszállásolásáról, ellátásáról, ő tájékoztatta a karhatalmi alakulat parancsnokát a kialakult helyzetről és az addig tett intézkedésekröl (ez utóbbit átengedhette a már ott tevékenykedő rendvédelmi alakulatok parancsnokának). Utasítást azonban nem adhatott katonai karhatalmi alakulatnak. ${ }^{49}$ Választások esetén a választási elnökhöz, kisebb helyiségekben a szavazatszedő küldöttség elnökéhez utalták. Ez az utalás azonban nem jelentett alárendeltséget vagy parancsadási jogot. ${ }^{50}$ Mindez teljesen megegyezett az 1914 elötti szabályzással. ${ }^{51}$

A katonai karhatalmi alakulat parancsnoka az azt kiküldő honvéd kerület-parancsnoka volt. Amennyiben az alakulat tevékenységét más kerületben fejtette ki, akkor a „fogadó” kerületparancsnokának alárendeltségébe került át. ${ }^{52}$ (Ez az átkerülés, katonai szakterminológiával átalárendelés, 1914 előtt is létezett. ${ }^{53}$ ) Az új alárendeltség 1934-től az alakulat elindulásakor lépett életbe, azt megelőzően a menetben lévő alakulat mindig annak a vegyesdandárnak az alárendeltségébe tartozott, amelyiknek a területén áthaladt. ${ }^{54}$ Más volt a helyzet a több kerületet egyidőben érintő karhatalmi intézkedések bevezetése esetén.

Az 1920-as években ilyen esetekben a Magyar Királyi Honvédség fóparancsnoka jelölt ki egy tábornokot, aki átvette a karhatalmi feladatokra kikülönített honvédalakulatok feletti parancsnokságot. ${ }^{55}$ A karhatalmi parancsnok a vezetésben azon vegyesdandár törzsére támaszkodott, amelynek területét a leginkább érintették a karhatalmi intézkedéseket kiváltó események. Hasonló módon oldották meg az egységes vezetést az ország egészét érintő karhatalmi intézkedések bevezetésekor, azzal a két fontos különbséggel, hogy a vezénylő tábornok a Magyar Királyi Honvédség Föparancsnoksága bázisán állította fel saját törzskarát, illetve hogy az egységes vezetés felállítását a honvédelmi és a belügyminiszter egyeztetésének kellett megelöznie. ${ }^{56}$

Budapesten a karhatalom parancsnoka az 1. vegyesdandár parancsnoka volt, a városparancsnokság (egyik) végrehajtó szervezetként lépett be a karhatalmi intézkedések bevezetésekor. Országos szintű intézkedések esetén a fővvárosi 1 . vegyesdandár parancsnoka közvetlenül a karhatalmi vezénylő tábornok alárendeltségébe tartozott. ${ }^{57}$

1929-ben az egységes vezetés rendszerét annyiban módosították, hogy az ország egészét érintő esetekben a Magyar Királyi Honvédség Főparancsnokságának Karhatalmi Főparancsnokságot kellett felállítania, amelynek megalakulásakor a két vezető szervezet szétvált egymástól. ${ }^{\mathbf{5 8}}$

1931-ben ezt újabb módosítás követte, amelynek értelmében az egységes irányítás bevezetésére, a Magyar Királyi Honvédség főparancsnokával egyetértésben és a honvédelmi miniszter hozzájárulásával, a belügyminiszternek kellett előterjesztést tennie a miniszterelnök felé. Az egységes vezetést ennek alapján a miniszterelnök rendelte el — minisztertanács elé nem volt köteles vinni a dolgot - melyet a honvédelmi miniszter foganatosított. ${ }^{59}$ Ugyanekkor írták elő „,..az alkotmányos kormányzás megbénitásának esetére...", hogy a Karhatalmi Föparancsnoksághoz a Magyar Királyi Belügyminisztériumnak egy fö csendőr és egy fö rendőr, valamint egy fö folyamör fötisztet, a Magyar 
Királyi Pénzügyminisztériumnak pedig egy fő főtisztviselőt, a Magyar Királyi Kereskedelmi Minisztériumnak pedig egy fö vasúti- és egy fő postai főtisztviselőt kellett delegálnia. ${ }^{\mathbf{6 0}}$

E személyek a Karhatalmi Főparancsnokság felállításakor a Magyar Királyi Honvédség föparancsnoka által (alkalomszerüen) kinevezett vezérkari főnök vezetése alatt, a Magyar Királyi Honvédelmi Minisztérium kiképzési osztálya és az 1. osztálya teljes személyi állományával, valamint a tárca VI/7.ö. és VI/7.k., továbbá a katonapolitikai osztály egy-egy előadójával, valamint a Katonai Főcsoportfőnökség összekötő tisztjével együtt alkották a Karhatalmi Főparancsnokság vezérkari osztályát. ${ }^{61}$

A budapesti 1. vegyesdandár-parancsnokságához a fővárosi rendőr-fökapitányságnak és a fővárosban székelő vidéki rendőr-főkapitányságnak, a Magyar Királyi Folyamőrségnek, csendőr kerületeknek és a budapesti révfőkapitányságnak kellett egy-egy fötisztet delegálnia országos karhatalmi készültség elrendelése esetén. ${ }^{62} \mathrm{~A}$ honvéd kerület-parancsnokok mellé csak a csendör kerületparancsnokok delegáltak kerületenként egy-egy tisztet. ${ }^{63}$

1931-ben egészítették ki a karhatalmi vezetési rendszert egy karhatalmi hadtest-parancsnoksággal és egy karhatalmi lovas hadosztály-parancsnoksággal. A hadtest-parancsnokság beékelődött a Karhatalmi Főparancsnokság és a vegyesdandár-parancsnokságok közé, a hadosztály-parancsnokság a dandárparancsnokságok strukturális szintjén alakult meg. Mindkét új parancsnokság csak az országos karhatalmi készültség elrendelésekor állt fel. Beiktatásuk a karhatalmi hadrendbe nem jelentette a Magyar Királyi Honvédségtől bevont erők növelését, a karhatalmi alakulatok létszáma csupán a parancsnokság személyi állományának a létszámával gyarapodott. ${ }^{64}$

További újdonságot jelentett 1931-ben, hogy a Karhatalmi Föparancsnokság közvetlen alárendeltségében létrehozták az országos karhatalmi készültség elrendelésekor felállítandó úgynevezett vári karhatalmi csoportot. A Magyar Királyi Testőrség parancsnokának alárendelt csoportba az összes, a Budai Várban elhelyezett testőr, honvéd-, rendőr- és koronaőr-alakulat beletartozott. Ugyanekkor osztották a budapesti 1. vegyesdandár-parancsnok alárendeltségében maradó karhatalmi erőket két karhatalmi csoportra: budaira és pestire. ${ }^{65} 1944$. X. 15-én és 16-án éjszaka - a háborúból történő kiugrási kísérlet és a német fegyverekkel támogatott nyilas hatalomátvételbe torkolló események időszakában — LÁZÁR Károly altábornagy, testőrparancsnok számára ez nyújtott lehetőséget az intézkedésre.

Ugyancsak 1931-ben rendelték el a katonai reáliskolák bevonását a karhatalmi rendszerbe. Tanintézetenként - az 1932-1933. tanév kezdetétöl — két karhatalmi századot kellett szervezni, tényleges tisztek parancsnoksága alatt, egyet a VII-VIII., egyet pedig az V-VI. évfolyam növendékeiből. A területileg illetékes vegyesdandár-parancsnoknak, szükséghelyzetben a legközelebbi állomásparancsnoknak alárendelt századokat csak a helyőrségben volt szabad alkalmaznia. ${ }^{66}$

1931-ben — arra az esetre, ha az államhatalmi szervezetek tevékenysége megbénulna kettéosztották az országot. A Dunától nyugatra eső területek úgynevezett teljhatalmú vezérlő tábornoka a 3., a Dunától keletre eső területeké pedig a 7. vegyesdandár-parancsoka lett volna. ${ }^{67}$ Hatalmukat az állami vezető szervezetek cselekvési szabadságának visszanyeréséig semmi sem korlátozta volna, még az esetlegesen mozgásszabadságukat megőrző kormánybiztosokat — a Dunától nyugatra eső területeken Zala, a Dunától keletre Borsod-Abaúj-Zemplén vármegye föispánja — is feleskették volna a maguk hüségére. ${ }^{68}$ A polgári hatóságok feletti intézkedési jogot 1912. évi, a kivételes hatalomról szóló törvényre alapozták. ${ }^{69} \mathrm{Az}$ ország területén ilyen esetben a polgári lakosság felett is a háború esetére szóló különleges büntetőjogi rendelkezések léptek volna életbe. ${ }^{70}$

Ez az eset feltételezte a Magyar Királyi Honvédség Főparancsnoksága és az általa felállítandó Karhatalmi Főparancsnokság cselekvésképtelenségét is. A két kerület-parancsnok közül a rangidősnek kellett átvennie a legfőbb állami végrehajtó hatalmat. Szükség esetén a dunántúli teljhatalmú vezénylő tábornokot a 2., a dunáninnenit a 6 . kerület parancsnoka helyettesítette. ${ }^{71}$

Ha a karhatalmi intézkedéseket kiváltó események a fôvárosban odáig fajultak volna, hogy a Budapesten állomásozó rendvédelmi és honvédalakulatok elfojtásukra elégtelennek bizonyultak volna, akkor a vidékről felhozott karhatalmat két csoportba osztották volna. A 3. honvéd kerület-parancsnok vezetése alatt megalakuló úgynevezett dunántúli karhatalmi csoportnak a budai oldalt, a 7 . honvéd kerület-parancsnok irányításával létrejövő dunáninneni karhatalmi csoportnak a pesti oldalt kellett volna előbb blokád alá vennie, majd a bekerítés teljessé válása után oda behatolnia. Abban az esetben tehát ha 
a szükséghelyzet a fóvárosra korlátozódott volna, akkor a budapesti karhatalmi csoport a tervek szerint megörizte áönállóságát. ${ }^{72}$

1914 előtt a kirendelt katonai karhatalom egységes vezetésére nem jött létre birodalmi, országos vagy országrésznyi igény, csupán a kirendelt erők parancsnoka kijelölésének elvét fogalmazták meg: ,,..az egész csoport feletti egységes parancsnoklás rendfokozat és rang szerint a legmagasabb parancsnokot illeti meg, tekintet nélkül arra, hogy az a közös hadsereghez vagy a honvédséghez tartozik-e." 73 amit „,nagyobb területre kiterjedt csendzavarások” esetén azzal toldottak meg, hogy „,...egy kiterjedt terület több pontján . . . a törvényes rend helyreállitására kirendelt csapatok egységes vezetésének biztositása czéljából az azok feletti parancsnoklás egy parancsnokra ruházandó". ${ }^{74}$ A karhatalmi törzsek felállitását is csak általában szabályozták: „Erösebb karhatalmaknál és ezeknek nagyobb területen való alkalmazásánál a parancsnokhoz megfelelö törzs (segédtisztek, orvosok, küldönczök stb.) osztandó be." 75 Látható, hogy a HORTHY-korban ezt a témakört sokkal részletesebben szabályozták, mint az Osztrák-Magyar Monarchia utolsó időszakában. A „szabad kéz elve” viszont épp az 1920 utáni szabályzatokból tủnt el: „A katonai müködés módja és a karhatalom tényleges alkalmazására irányuló katonai intézkedések kizárólag a katonai parancsnok belátásától függenek.", 76

\section{A honvéd karhatalom riasztási rendszere}

1930-ban vezették be a Magyar Királyság egész területét érintő esetekre vonatkozóan a kétfokozatú karhatalmi riasztási rendszert. ${ }^{77} 1914$ előtt ilyen nem volt. Az úgynevezett országos karhatalmi készültség elrendelését követően 6 óra állt rendelkezésre a vezető szerveezetek és a karhatalmi alakulatok megalakítására. Ez alatt el kellett érni a menetkészséget, amibe beleértendő volt az éleslőszer raktárakból való kihozása és felmálházása, ${ }^{78}$ illetve az, hogy a Magyar Királyi Honvédelmi Minisztérium 7/k. osztályának elő kellett készítenie a vasutakat az esetleges csapatszállítások lebonyolítására. ${ }^{79}$ (II.sz. melléklet) A felállított karhatalmi erők összlétszáma nem haladhatta meg a Magyar Királyi Honvédség, az egyes csapattestek által kiküldött karhatalmi alakulatok létszáma pedig az adott csapattest békelétszámának 50\%-át. ${ }^{80}$ (III.sz. melléklet) Tartalékosok behívása elővigyázatból, a tömegmozgalmaktól való félelem okán, nem szerepelt a karhatalmi utasításokban. A katonai vezetés megbízott az éppen szolgálatát teljesítő, így fegyelmezett állományban, ám tartott a szervezett szociáldemokrata munkások legénységre esetleg gyakorolt erkölcsi hatásától, s föként nem kívánt fegyvert adni a kezükbe. Ez különbözött az 1914 előtti szabályozástól, ugyanis akkor azt írták elő, hogy „,Karhatalom gyanánt alkalmazott minden gyalog és lovas század elvileg a teljes békelétszámmal vonuljon ki." ${ }^{81}$

A második fokozat az országos karhatalmi összevonás volt, melyet a készültségi fokozat elérése után rendelhetett el a Karhatalmi Főparancsnokság parancsnoka. Elrendelhették az összes, karhatalmi készültségbe helyezett alakulat számára, de elrendelhető volt részlegesen is. Ilyen esetben az összevonásra nem kerülő honvéd karhatalmi alakulatok készültsége továbbra is fennállt. ${ }^{82}$

Az összevonás elrendelését követően a kijelölt honvédségi karhatalmi alakulatoknak el kellett hagyniuk helyőrségeiket, hogy az elrendelő parancsban kijelölt körletekbe, nyilván a tömegmozgalmak által veszélyeztetettebb körzetekbe vonuljanak. $40 \mathrm{~km}$ távolságig gyalog, $60 \mathrm{~km}$-ig lovon hajtották végre a menetet, azon felül vasúti szállitással. ${ }^{83}$ Megalakítottak egy gépkocsioszlopot is a karhatalmi erők, illetve azok utánpótlásának szállítására. ${ }^{84} \mathrm{~A}$ belügyminiszter és a honvédelmi miniszter egyeztetését követően a Karhatalmi Föparancsnokság elrendelhette rendvédelmi alakulatok részvételét is az országos karhatalmi összevonásban. Ezen esetben az érintett, elsősorban csendőr-, Budapesten rendőralakulat a honvéd karhatalmi parancsnok alárendeltségébe lépett. Így került például a fövárosi rendőr karhatalom — karhatalmi ôrzászlóalj, azon belül lovasszázad, páncélgépjármüves század 10 Ansaldo kisharckocsival és 2 Csaba páncélgékocsival — az 1. vegyesdandár-parancsnok alárendeltségébe ${ }^{85}$ 1934-ben a Magyar Királyi Határôrséget kivonták a karhatalmi feladatokra igénybe vehető alakulatok köréböl. ${ }^{86}$

Az országos karhatalmi készültség elrendelésekor az esetleg kihelyezésen, gyakorlaton lévő alakulatoknak vissza kellett térniük helyőrségükbe, de elöbb — a 6 órás időhatáron belül — meg kellett alakítaniuk karhatalmi csoportjaikat. A vezényelteket és szabadságoltakat vissza kellett rendelni. A tanfolyamok hallgatóinak szintén vissza kellett térniük csapattestükhöz, a vezérkari tanfolyamot is beleértve. A készültség e három eleme azonban nem volt automatikus, végrehajtásukat külön rendelték el, a készültség bevezetésével egyidőben. ${ }^{87}$ 1931-től ezt az esetet karhatalmi állományfelemelésnek nevezték. ${ }^{88}$ 
Karhatalmi intézkedések bevezetésekor az érintett körzetekben külön rádióhálózatot - a korabeli szabályzatok terminológiájával rádióhálót — kellett kiépíteni, aminek 6 órán belüli müködőképességéért az adott területen fellépő karhatalmi parancsnokok feleltek. Országos kiterjedés esetén a híradási rendszer létrehozásába bevonhatóak voltak a polgári távközlési hálózatok is. Az így kiépített hálózatnak azonban függetlennek kellett maradni a Magyar Királyi Belügyminisztérium híradó rendszereitől. A karhatalmi hírközlő csatornákon csak rejtjelzett üzeneteket volt szabad továbbítani. ${ }^{89}$

1930-ban, évente két alkalommal, karhatalmi gyakorlat megtartását is elöírták. A gyakorlatokat az elkövetkezö években végrehajtották ugyan, de általában nem országosan, hanem 1-1 honvéd kerületre korlátozottan és a gyakorlatok során legtöbbször csak az első, tehát a készültségi szintet kellett elérni. ${ }^{90}$

A katonai vezetés az 1918-1919-es tapasztalatok alapján nem zárta ki a lehetőségét annak, hogy a tömegmozgalmak átterjedhetnek a Magyar Királyi Honvédség legénységi állományára. Ezt megelözendő kidolgozták az úgynevezett előkészítő rendelkezéseket, amelyek a katonai fegyelem megerősítését célozták. Ez az intézkedés-csomag két súlyossági fokozatra csoportosított rendelkezésekből állt. Az enyhébb esetekre vonatkozóan tartalmazta a politika bármely megnyilvánulásának fokozottabb távoltartását a katonáktól, a személyi állomány sajtó- és a levélcenzúráját, illetve a belépés szigorítását a honvédségi objektumokba, a katonák és a polgári lakosság érintkezésének korlátozását, a legénységi állomány ellátásának javítását, a tisztek közelebbre telepítését, szükség esetén bevonását lakásukról, az örzés-védelem megerösítését, adott esetben az együtt-tartás elrendelését. ${ }^{91}$

Az előkészítő rendelkezések között szerepelt - súlyosabb helyzetek kialakulásakor — a helyörség megerősítése, a portyázás bevezetése, egyes helyőrségen kívüli, de ahhoz közeli objektumok védelmének megszervezése, a lakosság csoportosulásának megakadályozása, sőt tüzér és/vagy aknavető alakulatok kiküldése, „...lázadó helységrészek rajtaütésszerü lövetése”. Ez már közelített a katonai diktatúra fentebb vázolt bevezetésének elvi lehetóségeihez. ${ }^{92}$

Ugyancsak az előkészítő intézkedések szabályozták az úgynevezett lakossági hirdetmények tartalmát és kifüggesztésének eseteit. ${ }^{93}$

Az Osztrák-Magyar Monarchia utolsó időszakában a katonákra történő átterjedés lehetőségének megelőzésére mindössze egyetlen mondat utalt: „A legénységnek a lakosságal való közelebbi érintkezése megakadályozandó." 94

\section{A honvéd karhatalom rendeltetése}

A karhatalmi feladatok végrehajtásának tanulmányozásakor a katonai karhatalom rendeltetéséből kell kiindulni. Ezt - a vizsgált korszakban - 1922-ben fogalmazták meg először, s lényegét tekintve egészen 1945-ig nem változtattak rajta: ,Az államhatalomnak, valamint az állami és társadalmi rendnek és a közbiztonságnak fenntartása vagy helyreállitása, továbbá a törvények végrehajtásáról való gondoskodás a közigazgatási (rendőri) hatóságok feladata. . . . végrehajtására a csendörség és egyéb fegyveres testületek és közegek állnak rendelkezésükre. . . . ha katonai karhatalmi erök igénybevétele feltétlenül szükséges, akkor vehetök csak igénybe karhatalmi szolgálatra a honvédség csapatai . . ." 95

$\mathrm{Az}$ 1924-es szabályzat a rendeltetést újrafogalmazta, ám megtartotta a két évvel korábbi megfogalmazás lényegét: „A katonai karhatalom rendeltetése az, hogy a polgári hatóságokat törvényes feladataik végrehajtásában, különösen pedig az állami és a társadalmi rend és a közbiztonság fenntartására, illetőleg helyreállitására irányuló müködésükben támogassa olyan esetekben, amikor a polgári hatóságok rendelkezése alá tartozó rendészeti alakulatok erre a célra nem elegendők." 96 Az ekkor alkotott fogalom gyakorlatilag visszatért az Osztrák-Magyar Monarchia utolsó időszakában megfogalmazott definícióhoz: „„Katonai karhatalom«-nak mindazokat a honvédségi csapatokat nevezzük, amelyek e szabályzatban meghatározott szerint a közhatóságok támogatása érdekében kirendeltettek. Tágabb értelemben karhatalmi szolgálat az elemi csapásoknál való segélynyújtás is. " 97

Az 1942-es fogalom, bár teljesen másként hangzott, inkább pontosította a katonai karhatalom meghatározását, de nem értelmezte újra a karhatalom általános definícióját: ,„»Katonai karhatalom《nak nevezzük mindazokat a honvédségi alakulatokat, amelyeket. . . az egész ország, vagy valamely részének közbiztonsága vagy az állam más életszükségleteinek biztositása érdekében, továbbá a közhatóságok támogatására kirendeltek. Tágabb értelemben karhatalmi szolgálat az elemi csapásoknál érvényesülő karhatalmi segélynyújtás is. "98 
A karhatalom fogalmát 1941-ben bontották ketté: kodifikálták azt, ami a gyakorlatban a kezdetektől funkcionált, legfeljebb nem két külön pontra bontottan: „,1. Katonai karhatalom az, amelyet közbiztonsági okból rendelnek ki. 2. Katonai segélynyújtás, vagy segédlet az, amelyet elemi csapások, vasúti forgalmi zavarok, árvizek, vagy hasonló esetekben idegen tárcák javára közérdekböl inkább munkára, mint közbiztonság céljából rendelnek ki.” 99 Érdekes, hogy 1942-ben a két pont „nem köszönt vissza".

Az 1906-os szabályzatban az olvasható, hogy „„Karhatalom«-nak azon csapatok neveztetnek, melyek a közhatóságok támogatására, alábbi határozványok szerint oly czélból rendeltetnek ki, hogy azoknak intézkedéseiknél és hivatalos ügyködéseiknél általában, föként pedig esetleges eröszakos ellentállás leküzdésére a szükséges anyagi erö rendelkezésre álljon. A. . . tágabb értelemben azon csapatok is »karhatalom«-nak fognak neveztetni, melyek az emlitett hatóságoknak elemi csapásoknál való segélynyujtás czéljából bocsáttatnak rendelkezésre." ${ }^{100} \mathrm{~A}$ rendeltetést tekintve is érdemes visszaidézni az 1906-os szabályzat megfogalmazását: „,Katonai karhatalom oly czélböl vehető igénybe, hogy a közhatóságok és azok közegei részéröl törvényes hatáskörükön belül a törvények végrehajtására, valamint a közbiztonság, csend és rend fentartására vagy helyreállitására irányuló intézkedéseknek, - amennyiben a rendelkezésükre álló eszközök ezen czélok elérésére már nem elégségesek - a kellö nyomatákot megadja. Ha a közhatóságok és közegeik emlitett czélokat egyéb intézkedésekkel is elérhetik, ez esetben katonai karhatalom nem veendö igénybe." 101

\section{A karhatalmi feladatok végrehajtása}

Az, hogy a Magyar Királyi Honvédség a korszakban mindvégig másodlagos szerepet játszott a karhatalom tekintetében, e meghatározásból következett. A konkrét cselekvések szintjén ez a másodlagosság azt jelentette, hogy a Magyar Királyi Honvédségtöl kiküldött karhatalmi alakulatok igyekeztek a háttérben maradni, puszta jelenlétükkel nyomatékot adni a rendvédelmi erők karhatalmi feladatainak a végrehajtásához. E háttérben maradást szinte szó szerint írták elö, a honvédségnek ,, . . . közvetlenül résztvennie sohasem szabad . . .” a karhatalmi jellegü tevékenységekben. Jelenlétével „, . . a közhatóságokat illetve ezek közegeit oltalmazza és rendelkezéseiknek a szükséges nyomatékot megadja ...” ${ }^{102}$, „.. . a rend és a közbiztonság fenntartására irányuló rendelkezésekhez a szükséges erőhatalmat zárt fellépéssel szolgáltassa.” ${ }^{103}$ Hasonló elöírások voltak érvényben 1914 előtt is: „A karhatalom alkalmazásánál elvül szolgáljon, hogy a csapatnak azon közegek. . . ügyködésében, a kikhez ki van rendelve, részt vennie sohasem szabad, hanem csupán . . . azokat oltalmazza és rendelkezéseiknek a szükséges nyomatékot megadja." 104

Abban az esetben azonban, ha az események elfajulása odáig vezetett, hogy a honvéd karhatalomnak magának kellett beavatkoznia, kemény szabályok léptek életbe. Lényegük, egyben céljuk az volt, hogy a katonák fellépése eldöntsön, lezárjon, ad absurdum véglegesen letörjön mindent. A követendő módszert pontosan meghatározták: „,Erély, mely ha kell, a kíméletlenségig fokozható, mindig célba vezet . . .”, hiszen „.. . a a habozás és a felelösségtől való félelem a kudarc forrása.” ${ }^{105}$ Az ennélfogva eleve erélyes fellépés közben „.. . . semmi szín alatt sem szabad egyezmény kötni, vagy bármily alkudozásba bocsátkozni." 106 Annak érdekében, hogy az erélyesség alatt minden parancsnok ugyanazt értse, a szabályzatok alkotói leszögezték, hogy: „, . . s sohasem szabad vak töltényekkel vagy a levegöbe felfelé löni." ${ }^{107}$ Ez utóbbihoz annyit azért hozzá kell tenni, hogy a honvéd karhatalom fellépését már meg kellett előzze a rendvédelmi testületekből létrehozott karhatalomé, tehát szó sem volt a tömegre figyelmeztetés nélkül leadott azonnali sortüzekről.

A mai előírásokhoz hasonlóan, a karhatalmi fegyverhasználatot többszöri felszólításnak kellett megelőznie. Attól függetlenül, hogy előzőleg a rendvédelmi testületek karhatalmi alakulata használt-e fegyvert, a katonai parancsnoknak háromszor fel kellett szólítania a tömeget cselekménye abbahagyására, majd ennek eredménytelensége esetén háromszor el kellett fújni a „,Tüzelj!” kürtjelet, illetve kürt hiányában három világító jelzőrakétát kellett fellőni, csak ezt követhette a fegyverhasználat. Az viszont azonnal emberre irányozva. ${ }^{108}$

Az erélyesség, sőt kíméletlenség követelményét az a szemlélet magyarázza, ami a szabályzók között szintén lefektetésre került: „. . . a fegyveres erö becsületének megóvását minden körülmények között biztositsa . . " az adott karhatalmi csoport fellépése. ${ }^{109}$

A felszólítást az összes vonatkozó utasítást a tömeg nagyobb részét alkotó etnikum anyanyelvén volt kötelező megtenni. ${ }^{110}$ Más kérdés, hogy a gyakorlatban ez a megkötés, kellő nyelvismeret hiányában, 
minden esetben érvényesülhetett-e volna. Mindenesetre ezt a szabályt a Magyar Királyi Honvédség létezésének végéig nem vonták vissza, ami az 1942 elején a Délvidéken történtek ismeretében különös helyzeteket teremtett.

A HORTHY-kori szabályzás ebben az esetben csak részben követte az 1914 előttit. Az 1906-os karhatalmi szabályzat ugyanis arra az esetre engedte meg a katonai karhatalom fegyverhasználatát, ,, $h a$ valamely csapat tettlegesen bántalmaztatik, vagy éppen fegyverrel támadtatik meg. . . és attól lehet tartani, hogy ez által a csapatok müködö képessége megakadályoztatnék vagy szerfölött korlátoztatnék” 111 és akkor is leszükítette azok körét, akik ellen fegyvert lehetett használni: „A fegyveres eröszakot ez alkalommal föként a mozgalom vezetöi ellen kell irányitani." fellépésre elöirt követelmények közül többet a HORTHY-kori szabályzatok is átvettek: ,....semmiféle ürügy alatt sem szabad bármily alkudozásba bocsátkozni, vagy egyezségre lépni” ${ }^{113}$; illetve „,... sohasem szabad vaktöltényekkel, vagy a levegöbe löni" 114 ; amelyet szuronyrohamnak kellett megelőznie, úgy, hogy az elött a „Roham!”, a tüzelés előtt pedig a „,Tüzelni!” jelet kellett kürtön fúvatni ${ }^{115}$; illetve azt is átvették az 1906-os karhatalmi szabályzatból, ha más megfogalmazásban is, hogy „.... a feladatok sikeres megoldása és a fegyverbecsület minden körülmények között biztositva legyen." 116

Ugyancsak az 1906-os karhatalmi szabályzatban található egy érdekes kitétel: „, Gyenge járőrök és különitmények alkalmazása mindig aggályos, mivel ezek könnyen legyözhetök, a mi pedig nagyon is alkalmas arra, hogy a zavargó tömeg vállalkozó kedvét fokozza." ${ }^{117}$ Hozzátehető ehhez, hogy a fegyverszerzési lehetőséget is megnöveli. Az 1924-es karhatalmi szabályzatba ugyanezt szinte szó szerint emelték át: „Gyenge járőrök és különitmények alkalmazása mindig aggályos, mert ezeknek könnyen bekövetkezhetö leküzdése a kihágásra hajló tömeg vállalkozó kedvét nagyon is fokozza." 118

Az esetleges fegyverhasználat - noha megelőzni, vagy kerülni igyekeztek azt - késlekedés nélküli elrendelése érdekében a karhatalmi feladatok végrehajtására kirendelt katonák — mai szakmai terminológiával — teljes lőszerjavadalmazásukat magukkal vitték: „,Minden csapat . . a löszert teljes szabványos kiméretben viszi magával.” 119 Nem volt ez másként 1914 előtt sem: „Minden fegyvernembeli csapatok. . a a teljes haditáska löszert . . . magukkal vigyék." 120

A HORTHY-korban több utasításban foglalkoztak azzal, hogy a megalakult honvéd karhatalmi csoportokat milyen sorrendben vessék be. 1931-től bevonták a karhatalmi feladatokra felriasztható csapatok körébe az akkor még rejtett repülőalakulatokat is. ${ }^{\mathbf{1 2 1}}$ 1934-ben aztán véglegesen szabályozták a fegyvernemek bevetési sorrendjét. Páncélgépjármüves osztagot kellett elsőként bevetni, ha elérhető távolságban volt. Ezt követte a gyalogság, majd a kerékpárosok, a tüzérség, a lovasság, végül a müszakiak. ${ }^{122}$ A repülők csak a Karhatalmi Föparancsnokság tartalékaként voltak alkalmazhatók. ${ }^{123}$ Kizárták viszont a karhatalmi célokra alkalmazható alakulatok köréből a légvédelmi tüzérséget. ${ }^{124}$ Ennek ellenére országos karhatalmi készültség elrendelésének esetére kijelöltek 3 légvédelmi-félüteget is. A Ferenc József-i korban ilyen bevetési sorrend nem létezett, a gyalogságot és a lovasságot egyaránt, egyszerre vagy külön-külön is alkalmazhatták, ${ }^{125}$ illetve elemi csapás elhárításában még a müszakiakat. ${ }^{126}$

Az 1942-ben kiadott karhatalmi szabályzat bővítette a karhatalmi feladatok körét. Kifejezetten a Magyar Királyi Csendőrség és a honvéd karhatalom feladatává tette a termelés folyamatosságának fenntartását a hadiüzemekben és az úgynevezett előkészületre kötelezett üzemekben, illetve a közlekedés zavartalanságának biztosítását. Ez sokkal összetettebb feladatot rótt a Magyar Királyi Csendőrségre és a Magyar Királyi Honvédségre, mint korábban egy esetleges sztrájk felszámolása. Elég, ha csak arra gondolunk, hogy az egyes katonai-, vagy csendőr-parancsnokoknak ad absurdum még termelésirányítási funkciókat is gyakorolniuk kellett. ${ }^{127}$

A karhatalmi alakulatok ellátásáért általában a felállító alakulat parancsnoka, az őfelette álló honvéd kerület-parancsnok, átirányítás esetén pedig az alkalmazási körzet illetékes honvéd kerület-parancsnoka felelt. Éles helyzetben a karhatalmi feladatokat végrehajtó honvéd személyeknek kiemelt élelmezés járt, ${ }^{128}$ sőt emelt illetmény is , a karhatalmi pótdij kiszabata a mindenkori szabályszerü napidijak 60 (hatvan) százalékában illetékes." ${ }^{129} 1914$ előtt a karhatalmi feladatok végrehajtására kirendelt katonáknak kiemelt élelmezés és pótilleték ugyancsak járt, ám ez utóbbi mértékét állománykategóriánként és rendfokozatonként külön, meghatározott összegben állapították meg. ${ }^{130}$ 
A HORTHY-korban és azt megelőzően egyaránt gondoltak arra is, hogy a karhatalmi fellépés esetleg sebesülésekkel járhat, úgy a katonák, mint a polgári személyek körében. „Minden karhatalomhoz lehetöleg orvost és megfelelö egészségügyi személyzetet kell beosztani"'131 írta elö az 1924-es karhatalmi szabályzat. Ez nem volt előzmény nélküli azonban, hiszen az 1906. évi karhatalmi szabályozás azt tartalmazta, hogy „Karhatalmak lehetöleg orvosokkal, valamint szükséges egészségügyi személyzettel is ellátandók." ${ }^{132}$ Egyik szabályzat sem utalt olyasféle korlátozásra, miszerint a kirendelt egészségügyisek csak a katonákat láthatnák el.

\section{Egy korszakon át}

A magyarországi tanácsköztársaság bukását követő időszakban a Magyar Nemzeti Hadsereg, majd Magyar Királyi Nemzeti Hadsereg, végül Magyar Királyi Honvédség karhatalmi szerepe belpolitikai szempontból jelentős volt. A bethleni konszolidáció elörehaladásával ez a szerepe fokozatosan csökkent, akárcsak az állam létére veszélyt jelentő tömegmozgalmak kialakulásának esélye. A megváltozott helyzetet tükrözték az 1922-1923. évek során kiadott karhatalmi utasítások és szabályzatok, illetve az 1923. IV. 27-ei minisztertanácsi ülés, amelynek egyik napirendi pontja „Az ország belsö rendjének hatályosabb védelme" volt. ${ }^{133}$

Az 1929-1933-as gazdasági világválság nyomán kirobbant megmozdulások arra késztették az állami és a katonai vezetést, hogy átgondolják és újra szabályozzák a Magyar Királyi Honvédség karhatalmi alkalmazásának rendszerét. Ennek során, elsősorban a honvédelmi tárca 1931. II. 3-ai és 1932. VII. 1jei vezetöi értekezletein, illetve az 1932. IV. 27-ei minisztertanácsi ülésen vetődött fel a katonai diktatúra megteremtésének gondolata. ${ }^{134} \mathrm{Az}$ adott szükséghelyzetben bevezetendő esetleges katonai diktatúra célja egyértelmüen az államhatalom megvédése, illetve helyreállítása volt. Az esetleges katonai diktatúrát bármely — tehát a politikai bal- és/vagy jobb — oldalról kiinduló tömegmozgalmak elleni védekezés szándéka hozta volna létre. Ezzel együtt, 1931-ben természetesen még a baloldaltól való félelem dominált. A gazdasági válság évei azonban nem csak a baloldali pártok és szervezetek aktivizálódását váltották ki, hanem ezekre az évekre esett a szélsőjobb nagyarányú térnyerése is Európában. A következő évtizedben csak pontosították, finomították a karhatalom struktúráját és alkalmazásának rendszerét. ${ }^{135}$

A Magyar Királyi Honvédség karhatalmi alkalmazásának újabb, átfogó átdolgozására már a háború expanzív szakaszában, 1941-1942-ben került sor, ennek ellenére a módosítások megfogalmazásában nem kis szerepet játszottak az 1940-es bányászsztrájk idején lezajlott karhatalmi akciósorozat tapasztalatai. ${ }^{136}$ Bár a magyar haderőt az adott időszakban elsődlegesen külső funkciójának ellátása kötötte le, belső feladatai nem csökkentek. Az állami és katonai vezetés abból indult ki, hogy a háború végjátékában — ellentétben 1918 végével — a Magyar Királyi Honvédségnek kell megőriznie az államrendet, a társadalmi viszonyokat, az országterületet, s mindazt, amit azok jelentettek. Ez a cél pedig nem tette lehetővé a magyar haderő karhatalmi szerepkörének és feladatrendszerének csökkentését. Annak elemzése viszont, hogy 1944-1945-ben a magyar haderő e feladat megvalósítása helyett milyen sorsra jutott és miért, egy másik tanulmány keretébe tartozik.

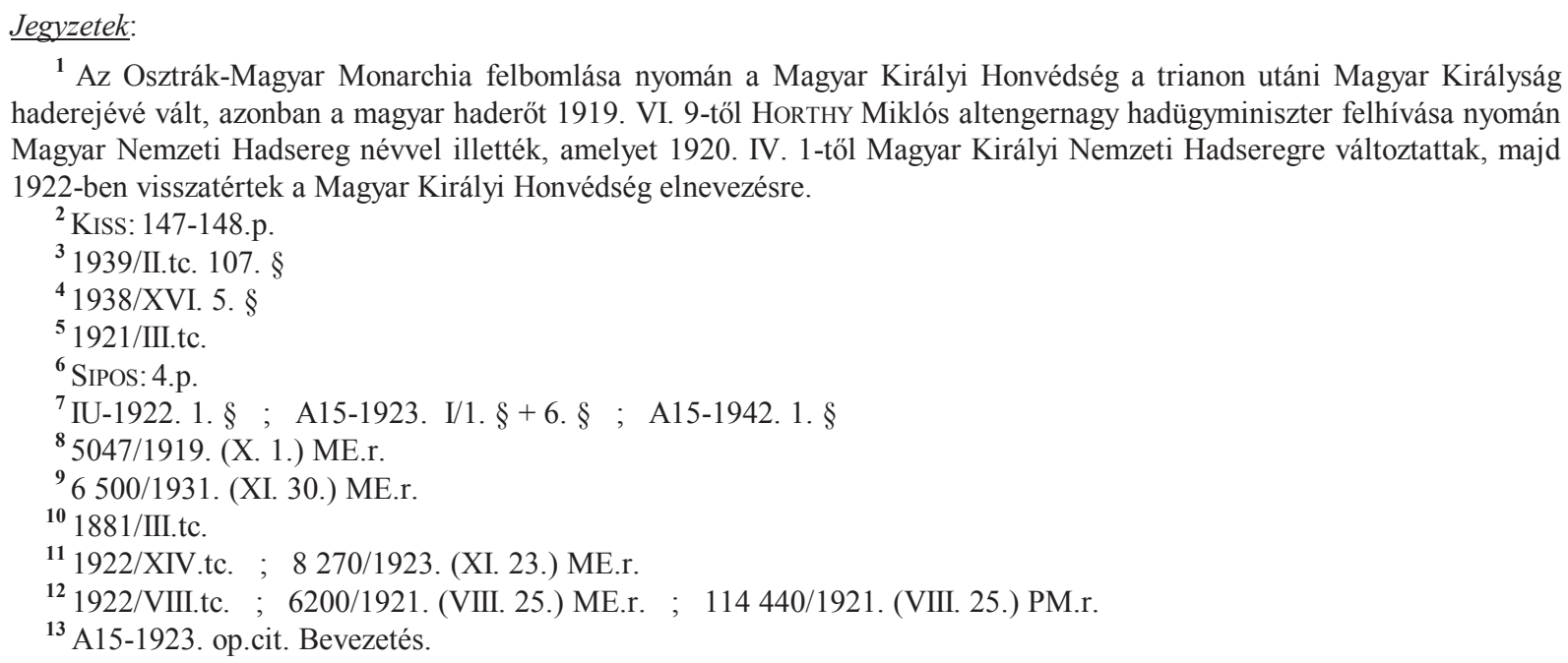


14 - A polgári magyar állam időszakában

katonailag szervezett fegyveres örtestület volt: a Magyar Királyi Csendőrség (1881-1945), az erdélyi és a horvátországi csendőr ezredek 1876-ban kerültek a magyar kormány fennhatósága alá és 1881-ben váltak a Magyar Királyi Csendőrség részévé, a Magyar Királyi Testőrség (reorganizálva 1867-1918), a Magyar Királyi Darabont Testörség (1904-1918), a Magyar Királyi Testőrség (1920-1945), a Magyar Királyi Koronaőrség (1867-1945), a Magyar Királyi Folyamőrség (19221939), a Magyar Királyi Vámőrség (1920-1931), a Magyar Királyi Határőrség (1932-1938)

polgári fegyveres örtestületek voltak: a magyarországi önkormányzatok rendőrségei a rendőrségek államosításáig [5047/1919. (X. 1.) ME.r.], az állami rendőrségek a Budapest Fővárosi Állami Rendőrség (1872-1919), a Magyar Királyi Határrendőrség (1906-1918), a Fiumei Magyar Királyi Állami Rendőrség (1916-1918), a Magyar Királyi Állami Rendőrség (1919-1931), a Magyar Királyi Rendőrség (1932-1945), a Magyar Királyi Pénzügyőrség (1867-1945), a Magyar Királyi Vám- és Adóőrség (1872-1886).

PARÁDI József: A katonailag szervezett örtestület és a polgári örtestület.

- A fegyveres örtestületek mellett a polgári magyar állam rendvédelmében részt vettek még az úgynevezett közhatósági jogú személyek is. Az erdőőrségek, gátőrségek, vasúti pályaőrségek stb. ugyanis nem képeztek sem katonailag szervezett fegyveres őrtestületet, sem pedig polgári fegyveres őrtestületet. Nem volt belső hierarchiájuk, parancsnokságuk, rangrendszerük stb. leginkább a XXI. század elején Magyarországon müködő személy- és vagyonbiztonsági szolgáltatást nyújtó cégekre hasonlítottak. Lényeges különbség volt azonban, hogy a korabeli erdőőrségek, gátőrségek, stb. nem biztonsági szolgáltatást nyújtó cégként ékelödtek be a rend fenntartására hivatott rendszerbe. A törvény kötelezte a jelentősebb mütárgyakat, természeti értékeket birtokló tulajdonosokat arra, hogy javaik védelme érdekében őrségeket alkalmazzanak. Így az erdőőrök foglalkoztatását — nagy kiterjedésű erdők kivételével, ahol a munkáltató az erdő tulajdonosa volt - az erdőbirtokosok társulása valósította meg. Hasonló volt a helyzet a víztársaságok esetében a gátőrségeket illetően is. A mezőőröket azonban már általában az önkormányzatok foglalkoztatták, esetleg a helyi érdekelt gazdák közössége. Más volt a helyzet a vasúti pályaörökkel (a korabeli köznyelvben bakteroknak nevezték őket), akiknek a foglalkoztatását a MÁV valósította meg, különösen a magyarországi vasúttársaságok koncentrálása nyomán. A belügyi tárca bocsátotta ki azon irányelveket, amelyek mentén a foglalkoztatók létrehozták a helyi — napjaink szóhasználata szerinti — szervezeti és müködési szabályokat, melyet a Magyar Királyi Belügyminisztérium hagyott jóvá. Ezen őrök számára a foglalkoztatók biztosítottak fizetést, formaruhát, lőfegyvert — bár a vasúti pályaőrök csak a XIX. században voltak felfegyverezve - és a szállást, amely a rájuk bízott területen álló kisebb családi házból és kertből állt, ahol a közhatósági jogú személy köteles volt lakni családjával. A közhatósági jogú személyek nem csupán őrizték a rájuk bízott javakat, hanem elvégezték a szükségessé váló egyszerübb karbantartási teendőket és felügyelték a kisjavitásokat is. Ebből fakadóan kettős képzettséggel kellett rendelkezniük, egyrészt például az erdőőröknek általában vadászvizsgával, a vasúti pályaőröknek a MÁV megfelelő tanfolyamának az eredményes elvégzésével stb., másrészt pedig valamennyi közhatósági jogú személynek — kizárólag a magyar állam által szervezett — a közhatósági jogú tevékenységre felkészítő tanfolyam eredményes vizsgájával is rendelkezniük kellett. Ennek nyomán tettek esküt a vármegyei elöljáróság elött a közhatósági jogú személyek. Olyan beosztásokba ahol ezen képesítés elő volt írva, kizárólag közhatósági esküvel rendelkező személyek voltak foglalkoztathatók. E munkakörök kettős értelemben is bizalmi állásnak voltak tekinthetők, mivel bünügyi feddhetetlenség mellett nemzethüség tekintetében is megrostálták e tanfolyamokra jelentkező személyeket. A közhatósági jogú személyeknek a rájuk bízott javakat dézsmáló, rongáló, vagy egyéb törvénybe ütköző cselekedeteket elkövetőket joguk és kötelességük volt elöállítani és a tiltott tevékenység eszközeit lefoglalni. A személyek ellen azonban már nem ők jártak el, hanem átadták az érintetteket a területileg illetékes rendőrhatóságoknak általában a kihívott rendőr- vagy csendőr járőr vette át ezen személyeket, valamint a lefoglalt tárgyakat további eljárás céljából. A közhatósági jogú személyeknek joguk volt intézkedésük során ellenállás esetében lőfegyvert is használni. A lőfegyverrel — amely lényegében bármilyen lehetett, általában azonban a honi fegyverkereskedelemben elöforduló vadászfegyverek voltak — és szolgálati jelvénnyel, amely foglalkoztatókként eltérő volt, a munkáltatók látták el a közhatósági jogú személyeket. Számukra a formaruha viselése amellyel szintén a foglalkoztatók látták el öket — is kötelezö volt. Ily módon könnyen és gyorsan — akár az írástudatlanok is - felismerhették a közhatósági jogú személyeket.

PARÁDi Ákos — PARÁdi József ; PARÁDI Ákos

- Karhatalmi teendők végzésére azonban a közhatósági jogú személyek alkalmatlanok voltak, nem rendelkeztek ugyanis egységes ruházattal, fegyverzettel, felszereléssel, továbbá a karhatalmi teendők ellátása tekintetében szervezetlenek és kiképzetlenek voltak. Hasonló volt a helyzet az önkormányzati rendőrségeket illetően is, mivel az önkormányzati rendőrségek tagjai önállóan szerezték be fegyvereiket és az egyenruhájuk is településenként változott, a többségük pedig karabéllyal sem rendelkezett. Csupán a karhatalom XIX. századi tágabb értelmezése szerinti azon tevékenységek megvalósítására voltak alkalmasak, amelyek foganatosítására fizikai erő alkalmazására, vagy annak közvetlen kilátásba helyezésére volt szükség mint például az idézésre a bíróság előtt meg nem jelenő személyek tárgyalásra való bekísérése, azonban csapaterős karhatalmi teendők ellátására alkalmatlanok voltak. A dualizmuskori állami rendőrségek — amelyek ruházata, felszerelése, fegyverzete már egységes volt — (fövárosi rendőrség, határrendőrség, fiumei rendőrség) körében sem alakultak ki karhatalmi tevékenység megvalósítására alkalmas szervezeti egységek, bár a fővárosi rendőrség létszáma már ezt lehetővé tehette volna ugyan, azonban mégis — először napi vezényléssel, majd stabil létszámmal — csapaterős karhatalmi teendőkre specializált szervezeti egységet, kezdetben század majd századkötelékben, csak a világháborút követően alakítottak ki. A karhatalmi feladatok ellátására alkalmas rendvédelmi testületek, amelyeknek e tevékenységi körrel a törvényekben lefektetett alapfeladatai is harmonizáltak, lényegében csupán a csendőrség és az államosított rendőrség volt. Létszámuk azonban testületenként csupán 12000 föt tett ki. a személyi állomány pedig szétszórva helyezkedett el. Nagyobb létszámot nem lehetett elvonni, mert az a közbiztonsági állapotok gyors romlását vonta volna maga után. A karhatalmi teendők ellátására alkalmas rendvédelmi testületek csupán kisebb létszámú karhatalmi alakulatok kialakítására voltak alkalmasak. Ez alól kivételt a budapesti rendőrség karhatalmi zászlóalja és a II. világháború során a Magyar Királyi Csendőrség kötelékében kialakított karhatalmi zászlóaljak jelentettek. A csendőr zászlóaljakat azonban már nem a hagyományos karhatalmi céllal állították fel, hanem — a II. világháború tapasztalatai alapján — a diverziós cselekedetek megelőzése és felszámolása érdekében.

PARÁDI József: Rendvédelem karhatalom 1867-1945. 
${ }^{15}$ A15-1923. op.cit. II/6. §

${ }^{16}$ A15-1942. op.cit.

${ }^{17}$ A15-1906. 4. §

${ }^{18}$ A15-1923. op.cit. I/2. $\S+\mathrm{II} / 5 . \S$

${ }^{19}$ Loc.cit. I/2. $\S+$ II/5. $\S+$ III/10. § ; HIM-HL HM.eln. 1.o. 1930/1638 és 1147/1923. Egységes vezetés karhatalmak felett nagyobb tömegmozgalmak esetére.

${ }^{20} \mathrm{~A} 15-1924.9$. §.

${ }^{21}$ Loc.cit. 9. §.

${ }^{22}$ Loc.cit. 9. §.

${ }^{23}$ A15-1906. op.cit. 10.

${ }^{24}$ Loc.cit. 10. §

${ }^{25}$ Loc.cit. 10. §

${ }^{26} \mathrm{~A} 15-1924.10 . \S$

${ }^{27}$ A15-1906. op.cit. 16. §

${ }^{28}$ A15-1923. op.cit. I/2. § + II/4. § ; A15-1942. op.cit. I/2. §+ 5. § ; HIM-HL HM.eln. 1. 1930/1938. és 8578/1929. Országos karhatalmi készültségbe helyezésröl és az országos karhatalmi összevonásról szóló intézkedés. ; HIM-HL. HM.eln. 1. 1935/1789. és 107 327/1935. Karhatalmak kirendelése választások alkalmával.

${ }^{29}$ A15-1923. op.cit. II/5. § ; A15-1942. op.cit. 2. §

${ }^{30}$ HIM-HL. HM.eln. 1. 1935/1789. és 107 327/1935. Karhatalmak kirendelése választások alkalmával. op.cit.

${ }^{31}$ A15-1906. op.cit. 2. §

${ }^{32}$ A15-1923. op.cit. I/2. § ; A15-1942. op.cit. 2. §

${ }^{33}$ A15-1906. op.cit. 1.sz. melléklete.

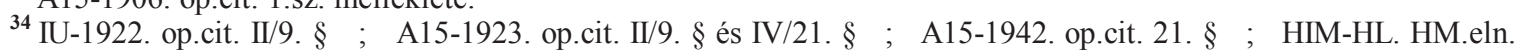

1. 1935/1789. és 107 327/1935. Karhatalmak kirendelése választások alkalmával. op.cit.

${ }^{35}$ A15-1906. op.cit. 13. §

${ }^{36}$ A15-1923. op.cit. II/5. § és II/12. § ; A15-1942. op.cit. 5. § ; HIM-HL HM.eln. 1. 1930/1938. és

8578/1929. Országos karhatalmi készültségbe helyezésről és az országos karhatalmi összevonásról szóló intézkedés. op.cit.

1. pont.

${ }^{37}$ A15-1906. op.cit. 3. §

${ }^{38}$ A15-1923. op.cit. II/5. § és III/18. § ; A15-1942. op.cit. I5. § ; HIM-HL HM.eln. 1. 1931/1789 és 105

175/1931. Karhatalmi titkos intézkedés. II/3. pont.

${ }^{39}$ A15-1906. op.cit. 12. §

${ }^{40}$ Loc.cit. 3. §

${ }^{41}$ Loc.cit. 12 . $\S$

${ }^{42}$ A15-1923. op.cit. I/2. § és II/5. § ; A15-1942. 5.§

${ }^{43}$ A15-1906. op.cit.12. §

${ }^{44}$ HIM-HL HM.eln. 1. 1931/1789 és 105 175/1931. Karhatalmi titkos intézkedés. op.cit. II/4. pont.

${ }^{45}$ A15-1923. op.cit. I/2. § és II/5. § ; HIM-HL HM.eln. 1. 1931/1789 és 105 175/1931. Karhatalmi titkos intézkedés. II/4. pont. op.cit.

${ }^{46}$ A15-1923. op.cit. II/3. § ; A15-1942. op.cit. 3. § ; HIM-HL HM.eln. 1. 1931/1789 és 105 175/1931. Karhatalmi titkos intézkedés. op.cit. I/1. pont.

${ }^{47}$ A15-1906. op.cit. 9. §

${ }^{48}$ VARGYAI: 99-101.p.

${ }^{49}$ A15-1923. op.cit. II/6. § + III/18. § ; A15-1942. op.cit. 6. §

${ }^{50}$ IU-1922. op.cit. II/9. § ; HIM-HL. HM.eln. 1. 1935/1789. és 107 327/1935. Karhatalmak kirendelése választások alkalmával. op.cit. ; A15-1942. op.cit. 9. §

${ }^{51}$ A15-1906. op.cit. 9. $\S+10 . \S+11 . \S$

52 A15-1923. op.cit. III/16. § ; A15-1942. op.cit. 17. $\quad ; \quad$ HIM-HL HM.eln. 1. 1931/1789 és 105

175/1931. Karhatalmi titkos intézkedés. op.cit. II/3. pont.

${ }^{53}$ A15-1906. op.cit. 22. §

${ }^{54}$ HIM-HL HM.eln. 1. 1930/1938. és 8578/1929. Országos karhatalmi készültségbe helyezésről és az országos

karhatalmi összevonásról szóló intézkedés. op.cit. B/4. pont. ; HIM-HL HM.eln. op.cit. 1. 1931/1789. és 200 013/1931.

${ }^{55}$ A15-1923. op.cit. III/12. §

${ }^{56}$ Loc.cit. III/12. §

${ }^{57}$ HIM-HL HM.eln. 1. 1931/1789 és 105 175/1931. Karhatalmi titkos intézkedés. op.cit. ; HIM-HL HM.eln. op.cit.

1. 1930/1638. és $10871 / 1930$.

${ }^{58}$ HIM-HL HM.eln. 1. 1930/1938. és 8578/1929. Országos karhatalmi készültségbe helyezésről és az országos karhatalmi összevonásról szóló intézkedés. op.cit. A/IV. pont.

${ }^{59}$ HIM-HL HM.eln. 1. 1931/1789 és 105 175/1931. Karhatalmi titkos intézkedés. op.cit. II/1.pont.

${ }^{60}$ Loc.cit. II/2.

${ }^{61}$ HIM-HL.eln.1. op.cit. 1930/1639. és 118 041/1930. Honvéd Főparancsnokság Törzsének egységes vezetés esetén való megalakulásának újólagos szabályozása.

${ }_{62}^{2}$ HIM-HL HM.eln. 1. 1931/1789 és 105 175/1931. Karhatalmi titkos intézkedés. op.cit. II/2.pont.

${ }^{63}$ Loc.cit. II/2.pont.

${ }^{64}$ HIM-HL HM.eln. 1. 1931/1789 és 105 175/1931. Karhatalmi titkos intézkedés. op.cit. I/5.pont.

${ }^{65}$ Loc.cit. IV/A.

${ }^{66}$ HIM-HL.HM.eln.1. 1935/3370. és 117 065/1931. Reáliskolai nevelőintézetek növendékeinek karhatalmi alkalmazása.

${ }^{67}$ HIM-HL HM.eln. 1. 1931/1789 és 105 175/1931. Karhatalmi titkos intézkedés. op.cit. IV/B.pont.

${ }^{68}$ Loc.cit. IV/B.pont.

${ }^{69}$ 1912/LXIII.tc.

${ }^{70}$ HIM-HL HM.eln. 1. 1931/1789 és 105 175/1931. Karhatalmi titkos intézkedés. op.cit.

${ }_{72}^{71}$ Loc.cit. IV/C.pont.

${ }^{72}$ Loc.cit. III.pont + IV/A.pont. ; HIM-HL HM.eln. 1. 1930/1938. és 8578/1929. Országos karhatalmi készült-

ségbe helyezésról és az országos karhatalmi összevonásról szóló intézkedés. op.cit. Melléklet.

${ }^{73}$ A15-1906. op.cit. 18. § 
${ }^{74}$ Loc.cit. $9 . \S$

${ }^{75}$ Loc.cit. 18 . §

${ }^{76}$ Loc.cit. 18. $\S$

77 HIM-HL HM.eln. 1. 1930/1938. és 8578/1929. Országos karhatalmi készültségbe helyezésről és az országos karhatalmi összevonásról szóló intézkedés. op.cit. A/I.pont.

${ }^{78}$ Loc.cit. A/II.pont.

${ }^{79}$ Loc.cit. B/III.pont.

${ }^{80}$ HIM-HL HM.eln. 1. 1930/1938. és 8578/1929. Országos karhatalmi készültségbe helyezésről és az országos karhatalmi összevonásról szóló intézkedés. op.cit. A/III.pont.

${ }_{81}^{81}$ A15-1906. op.cit. 19. §

${ }^{82}$ Loc.cit. P/I.pont.

${ }^{83}$ Loc.cit. B/II.pont.

${ }^{84}$ Loc.cit. 1.sz. melléklet.

${ }^{85}$ Loc.cit. 1.sz. melléklet. ; HIM-HL HM.eln. 1. 1931/1789 és 105 175/1931. Karhatalmi titkos intézkedés. op.cit. II/I.pont.

${ }^{86}$ HIM-HL HM.eln. 1. 1931/1789. és 200 013/1931. op.cit.

${ }^{87}$ HIM-HL HM.eln. 1. 1930/1938. és 8578/1929. Országos karhatalmi készültségbe helyezésről és az országos karhatalmi összevonásról szóló intézkedés. op.cit. A/IV.pont.

${ }^{88}$ HIM-HL-HM.eln. 1. 1931/1789. és 3370/1931. Karhatalmi nyílt intézkedések.

${ }^{89}$ HIM-HL HM.eln. 1. 1930/1938. és 8578/1929. Országos karhatalmi készültségbe helyezésről és az országos karhatalmi összevonásról szóló intézkedés. op.cit. A/VI.pont. ; HIM-HL HM.eln. 1. 1931/1789 és 105 175/1931. Karhatalmi titkos intézkedés. op.cit. I/5.pont.

${ }^{90}$ HIM-HL HM.eln. 1. 1930/1938. és 8578/1929. Országos karhatalmi készültségbe helyezésröl és az országos karhatalmi összevonásról szóló intézkedés. op.cit. D.pont.

${ }_{91}$ A15-1923. op.cit. III/10. § 3. + 5. + 6. pontok. ; A15-1942. op.cit. 11. §

${ }^{92}$ A15-1923. op.cit. III/10. § 3. 1. +2. + 4. pontok. ; A15-1942. 11. § op.cit.

${ }_{93}$ A15-1923. op.cit. III/10. § 7. pontok. ; A15-1942. 11. § op.cit.

${ }^{94}$ A15-1906. op.cit. 11. §

95 IU-1922. 1. §

${ }^{96}$ A15-1924. 1. §

${ }_{97}^{97}$ Loc.cit. Elözetes észrevételek.

${ }^{98}$ A15-1942. op.cit. Bevezetés.

${ }^{99}$ HIM-HL. HM.eln. H-1941. 3500. Vezérfonal a gyakorlatok, kihelyezések és karhatalmi kirendelések alatt követendő gazdasági, közigazgatási szabályokról. VIII.pont A/1-2.pont.

${ }^{100}$ A15-1906. op.cit. Bevezetés.

${ }^{101}$ Loc.cit. I. fejezet $1 . \S$

${ }^{102}$ A15-1942. op.cit. 6. §

${ }^{103}$ Loc.cit. $9 . \S$

${ }^{104}$ A15-1906. op.cit. 4. §

${ }^{105}$ A15-1923. op.cit. II/6. § ; A15-1942. 6. § op.cit.

${ }^{106}$ A15-1923. op.cit. II/7. §

${ }^{107}$ Loc.cit. II $/ 7$. §

${ }^{108}$ IU-1922. op.cit. II/7. § ； A15-1923. II/7. § op.cit. ； A15-1942. op.cit. 7. §

${ }^{109}$ A15-1923. op.cit. III/11. §

${ }^{110} \mathrm{IU}-1922 . \mathrm{II} / 7$. § op.cit. ; A15-1923. II/7. § op.cit. ; A15-1942. op.cit. 7. §

${ }^{111}$ A15-1906. op.cit. 5. §

112 Loc.cit. 5. §

${ }^{113}$ Loc.cit. 5. $\S$

${ }^{114}$ Loc.cit. $5 . \S$

${ }^{115}$ Loc.cit. 5. §

${ }^{116}$ Loc.cit. $17 . \S$

${ }^{117}$ Loc.cit. $18 . \S$

${ }^{118}$ A15-1924. op.cit. 12. §

${ }^{119}$ Loc.cit. 13. §

${ }^{120}$ A15-1906. op.cit. 20. §

${ }^{121}$ HIM-HL HM.eln. 1. 1931/1789 és 105 175/1931. Karhatalmi titkos intézkedés. op.cit. I/1.pont.

${ }^{122}$ HIM-HL HM.eln. 1. 1931/1789. és 200 013/1931. op.cit.

${ }^{123}$ HIM-HL HM.eln. 1. 1931/1789 és 105 175/1931. Karhatalmi titkos intézkedés. I/1.pont. op.cit.

${ }^{124}$ HIM-HL HM.eln. 1. 1931/1789. és 200 013/1931. op.cit.

${ }^{125}$ A15-1906. op.cit. 6. §

${ }^{126}$ Loc.cit. 13-15. §

${ }^{127}$ A15-1942. op.cit. 1. $\S+10 . \S$ A., B., C.,

128 HIM-HL HM.eln. 1. 1930/1938. és 8578/1929. Országos karhatalmi készültségbe helyezésről és az országos karhatalmi összevonásról szóló intézkedés. op.cit. C.pont. 
${ }^{129}$ HIM-HL.HM.eln. 4559/eln.6.1. Illetményszabályzat (G-10) a Magyar Királyi Honvédség számára. III. Fejezet 8. §

${ }^{130}$ A15-1906. op.cit. 27. §

${ }^{131}$ Loc.cit. 19. §

${ }^{132}$ A15-1924. op.cit. 11. §

${ }^{133}$ IU-1922. op.cit. ; A15-1923. op.cit. ; VARGYAI: op.cit. 98.p.

${ }^{134}$ VARGYAI: op.cit. 99-100.p. ; HIM-HL HM.eln. 1. 1930/1938. és 8578/1929. Országos karhatalmi készültségbe helyezésről és az országos karhatalmi összevonásról szóló intézkedés. op.cit. ； HIM-HL HM.eln. 1. 1930/1638. és 10871/1930. op.cit. ; HIM-HL.eln.1. 1930/1639. és 118 041/1930. Honvéd Főparancsnokság Törzsének egységes vezetés esetén való megalakulásának újólagos szabályozása. op.cit. ; HIM-HL HM.eln. 1. 1931/1789. és 200 013/1931. op.cit. ; HIM-HL HM.eln. 1. 1931/1789 és 105 175/1931. Karhatalmi titkos intézkedés. op.cit. ; HIM-HL-HM.eln. 1. 1931/1789. és 3370/1931. Karhatalmi nyílt intézkedések. op.cit. ; HIM-HL.HM.eln. 1. 1930/1638. és 1155/T-1/1924. A honvédség főparancsnokának törzse egységes vezetés esetén. ; HIM-HL.HM.eln. 1. 1930/1638. és 11165/1929. Országos karhatalmi készültségre vonatkozó rendelethez gazdászat-közigazgatási intézkedések.

${ }^{135}$ HIM-HL.HM.eln. 1. 1935/3370. és 5500/1932. Karhatalom kirendelésének, erejének és alkalmazásának szabályozása. ; HIM-HL.HM.eln. 1. /3370. és 5840/1932. Karhatalmi intézkedések helyesbítése. ; HIM-HL.HM.eln.1. 1935/1789. és 107 327/1935. Karhatalmak kirendelése választások alkalmával. ; HIM-HL.HM.eln. 1. 1935/3370. és 101 947/1931. ; HIM-HL HM.eln. 1. op.cit. 1935/3370. és 110 500/1932. Karhatalmi titkos intézkedés. ; HIM-HL.HM.eln. 1. op.cit. 1935/3370. és 115 242/1932. Karhatalmi titkos intézkedések helyesbítése. ; HIM-HL.HM.eln. 1. op.cit. 1935/3370. és 108 000/1934. Karhatalmak kirendelésének, erejének és alkalmazásának szabályozása. ; HIM-HL.HM.eln. 1. op.cit. 1935/3370. és 115 322/1934. A karhatalomról szóló 108 000/HM.Eln. 1. /1934.sz. rendelet helyesbítése. ; HIMHL.HM.eln. 1. op.cit. 1935/3370. és 117 961/1934. A karhatalomról szóló 108 000.HM.Eln. 1./1934.sz. rendelet mellékleteinek helyesbítése.

136 15-1942. op.cit.

Jegyzetekben alkalmazott röviditések:

\section{MONOGRÁFIÁK, KISMONOGRÁFIÁK ÉS HASONLÓ JELLEGỦ KÖTETEK}

PARÁDI Ákos — PARÁd József

(14.;)

VARGYAI

(48.;133.;134.;)

\section{TANULMÁNYOK}

PARÁdi Ákos

PARÁDI József: Rendvédelem karhatalom 1867-1945.

(14.;)

PARÁDI József: A katonailag szervezett örtestület és a polgári őrtestület.

(14.;)

\section{LEXIKONOK}

KISS

(2.;)
PARÁdi Ákos - PARÁdI József: Rendvédelmünk 1867-1945. Budapest, 2006, Rendőrtiszti Főiskola. 81 p. HU-ISBN 9630602814.

- VARgYal Gyula: A hadsereg politikai funkciói Magyarországon a harmincas években. Budapest, 1983, Akadémiai Kiadó. 190 p. HU-ISBN 9630530856.

- PARÁdi Ákos: A magyar rendvédelem civil szerveződései 1867-1945. Rendvédelem-történeti Füzetek (Acta Historiae Preasidii Ordinis), XV. évf. (2008) 18. sz. 64-87.p. A tanulmány korábbi változata 2004. október 13.-án Budapesten hangzott el, a Szemere Bertalan Magyar Rendvédelem-történeti Tudományos Társaság által szervezett rendvédelem-történeti tudományos konferencia-sorozatnak ,Karhatalmi feladatok a bünmegelőzés és a békefenntartás szolgálatában Európában a XIX-XX. században” címü XVIII. konferenciáján. A publikált tanulmány az előadás javított, bővített és átdolgozott változata.

PARÁDI József: Rendvédelem karhatalom 1867-1945. Rendvédelem-történeti Füzetek (Acta Historiae Preasidii Ordinis), XX. évf. (2011) 23. sz. 111-123. p. A tanulmány korábbi változata 2009. október 9.-én Budapesten hangzott el, a Szemere Bertalan Magyar Rendvédelem-történeti Tudományos Társaság által szervezett rendvédelem-történeti tudományos konferencia-sorozatnak „, $\mathrm{k} \mathrm{ki-}$ egyezéstöl az ezredfordulóig felszámolt országos hatáskörü magyar rendvédelmi testületek." című XXIII. konferenciáján. A publikált tanulmány az előadás javított, bővített és átdolgozott változata.

PARÁDI József: A katonailag szervezett örtestület és a polgári örtestület. Rendvédelem-történeti Füzetek (Acta Historiae Praesidii Ordisnis), XXV.évf. (2015) 43-44-45-46.sz. 77-84.p. HU-ISSN 1216-6774.

KISS István Géza: Hadiüzem, Hadiüzemi biztosítás, Hadiüzemi megbízott, Hadiüzemi őrség, Hadiüzemi személyzeti parancsnok. szócikkek 147148.p. In Sipos Péter — RAVASZ István (szerk.): Magyarország a második világháborúban. Lexikon A - Zs. Budapest, $1997^{2}$, Petit Real Könyvkiadó. 592 p. HU-ISBN 9638541156. 


\section{CIKKEK}

SIPOS

(6.;)

\section{SZABÁLYZATOK}

A15-1906

(17.;23.;24.;25.;27.;31.;33.;35.;37.; 39.;40.;41.;43.;47.;51.;53.;73.;74.;

75.;76.;81.;93.;100.;101.;104.;111.;

112.;113.;114.;115.;116.;117.;120.; 125.;126.;130.;131.;

A15-1923

(7.;15.;18.;19.;28.;29.;32.;34.;36.;38.; 42.;45.;46.;49.;52.;55.;56.;91.;92.;93.; 105.;106.;107.;108.;109.;110.;133.;)

A15-1924

(20.;21.;22.;26.;28.;96.;97.;118.;119.; 132.;)

A15-1942

(7.;16.;29.;32.;34.;36.;38.;42.;46.;49.; 50.;42.;91.;92.;93.;98.;102.;103.;105.; 108.;110.;127.;136.;)

IU-1922.

(7.;34.;34.;50.;95.;108.;110.;133.;)
Sipos Péter: A Horthy-kormányzat a szélsőjobb ellen. História, XVII.évf. (1995) 9-10.sz. 3-5.p. HU-ISSN 0139-2409.

- Utasitás a cs. és kir. közös hadseregbeli vagy m. kir. honvéd karhatalmaknak igénylése, kirendelése és alkalmazására nézve. Budapest, 1906, Pallas Irodalmi és Nyomdai Részvénytársaság. 60 p.

Szabályzat a karhatalmi szolgálat ellátására a m. kir. Honvédség számára. Budapest, 1923, Magyar Királyi Honvédelmi Minisztérium.

- Szabályzat a karhatalmi szolgálat ellátására a m. kir. Honvédség számára. Budapest, 1924, Magyar Királyi Honvédelmi Minisztérium.

- A-15. Szabályzat a karhatalmi szolgálat ellátására a Magyar Királyi Honvédség számára. Budapest, 1942, Athenaeum. 104 p.

Ideiglenes utasitás a karhatalmi szolgálat ellátására a m. kir. Honvédség számára. Budapest, 1922, Magyar Királyi Honvédelmi Minisztérium.

\section{LEVÉL- IRAT ÉS DOKUMENTUMTÁRAK}

HIM-HL HM.eln.

(19.;28.;30.;34.;36.;38.;44.;45.;46.; 50.;52.;54.;57.;58.;59.;60.;61.;62.; 63.;64.;65.;66.;68.;70.;71.;72.;77.; 78.;79.;80.;83.;84.;85.;86.;87.;88.; 89.;90.;99.;99.;121.;122.;123.;124.; 128.;129.;134.;135.;)

\section{JOGSZABÁLYOK}

1881/III.tc.

(10.;)

1912/LXIII.tc.

(69.;)

1921/III.tc.

(5.;)

1922/VIII.tc.

(11.;)

1922/XIV.tc.

(11.;)

1938/XVI.tc.

(4.;)

1939/II.tc.

(3.;)

5047/1919. (X. 1.) ME.r.

(8.;)

6 200/1921. (VIII. 25.) ME.r.

114 440/1921. (VIII. 25.) PM.r. (12.;)

8 270/1923. (XI. 23.) ME.r.
Hadtörténeti Intézet és Múzeum, Hadtörténeti Levéltára, Honvédelmi Minisztérium elnökségi iratainak gyűjteménye.

— 1881/III.tc. a közbiztonsági szolgálat szervezéséről.

— 1912/LXIII.tc. a háború esetére szóló kivételes intézkedésekről.

— 1921/III.tc. az állami és a társadalmi rend hatályosabb védelméről.

1922/VIII.tc. a Magyar Királyi Vámőrség, a Magyar Királyi Pénzügyőrség létszámának, kiegészítési módjának és felfegyverkezésének megállapításáról.

— 1922/XIV.tc. a Magyar Királyi Folyamőrség szervezéséről, létszámának, kiegészítési módjának és felfegyverkezésének megállapításáról.

1938/XVI.tc. az állami rend megóvása végett szïkséges büntetőjogi rendezésekről.

1939/II.tc. a honvédelemröl.

5047/1919. (X. 1.) ME.r. a rendőrség államosításáról.

Magyarországi Rendeletek Tára, LIII.évf. (1919) I.füzet. 752-767.p.

6 200/1921. (VIII. 25.) ME.r. a vámőrség létesítéséről.

Magyarországi Rendeletek Tára, LV.évf. (1922) I.füzet. 223-232.p.

114 440/1921. (VIII. 25.) PM.r. a vámőrség létesítéséről szóló 6.200/1921. M.E. számú kormányrendelet végrehajtásáról.

Magyarországi Rendeletek Tára, LV.évf. (1922) I.füzet. 1594-1623.p.

- $\quad 8$ 270/1923. (XI. 23.) ME.r. a folyamrendészet gyakorlásáról és a m. kir. fo- 
lyamőrség szervezéséröl, létszáma kiegészitési módjainak és felfegyverzésének megállapításáról szóló 1922: XIV. tc. végrehajtásáról.

Magyarországi Rendeletek Tára, LVII.évf. (1924) I.füzet. 335-340.p.

6 500/1931. (XI. 30.) ME.r.

6 500/1931. (XI. 30.) ME.r. a m.kir. rendőrség szervezeti változásairól.

\section{Mellékletek jegyzéke:}

I.sz. melléklet.

Katonai karhatalmi beavatkozás igénylésére jogosultak listája.

II.sz. melléklet.

A Magyar Királyi Honvédség által felállítandó karhatalmi alakulatok harcrendje és harcértéke országos karhatalmi készültség elrendelése után.

III.sz. melléklet.

A katonai karhatalmi harcoló állomány létszáma, fegyverzete és lőszerjevadalmazása.

\section{Katonai karhatalmi beavatkozás igénylésére jogosultak listája.}

I.sz. melléklet.

- Miniszterek;

- a belügyminiszter helyett az országos rendőrfőkapitány is, a budapesti és a kerületi rendőrfőkapitányok — majd a budapesti és a vidéki rendőrfőkapitány — a rendőrkapitányok és a rendőri kirendeltségek vezetői;

- csendőr-parancsnokok és szolgálatban lévő csendörök;

- révfőkapitány és révkapitányok valamint révkirendeltségeinek vezetői, továbbá folyamőr parancsnokok és folyamőr hajó-parancsnokok;

- a Magyar Királyi Vámőrség országos parancsnoka, a vámőr kerület-parancsnokok és a vámőr szakasz-parancsnokok;

- a föügyészségek és ügyészségek vezetői és nyomozást végző tagjai;

- a törvényszékek elnökei, a járásbíróságok vezetői és nyomozást végző bírái, valamint a törvényszéki vizsgálóbírák;

- az országos fegyintézetek, kerületi börtönök, közvetítő intézetek és gyüjtőfogházak igazgatói;

- föispánok, az alispánok, a polgármesterek, a föszolgabírák, a községi bírák vagy azok helyettesei együttesen a községi jegyzőkkel illetve a körjegyzőkkel;

- a köz-, illetve az állategészségügyi törvény alapján kiküldött kormánybiztosok;

- az árvízvédelmi miniszteri biztosok;

- a posta- és távirdaigazgatóságok vezetői;

- a pénzügyigazgatóságok vezetői, pénzügyőri biztosi kerületek vezetői és a pénzügyőri előadók;

- a központi vámigazgatóság vezetője, a vámhivatalok vezetői;

- az adófelügyelöségek vezetői és az adóhivatalok fönökei,

- a bányakapitányságok vezetői;

- a dohánygyárak igazgatói;

- országos közintézetek igazgatói;

- a mügyüjtemények és múzeumok igazgatói;

- az állam- és magánvasutak igazgatóságainak vezetői, üzletigazgatóságainak vezetői, üzletvezetői, állomásfőnökei és osztálymérnökei,

- a hadiüzemek katonai megbízottjai (utóbbiak csak 1940-től).

Forrás ! - Szabályzat a karhatalmi szolgálat ellátására a m. kir. Honvédség számára. Budapest, 1923, Magyar Királyi Honvédelmi Minisztérium. 12. §

- Szabályzat a karhatalmi szolgálat ellátására a Magyar Királyi Honvédség számára. Budapest, 1942, Athenaeum. 104 p. Függelék. 
II.sz. melléklet.

\section{A Magyar Királyi Honvédség által felállitandó karhatalmi alakulatok harcrendje és harcértéke országos karhatalmi készültség elrendelése után.}

- 7 karhatalmi ezred, ezen belül: 14 gyalog zászlóaljban 42 század, valamint 2 géppuskás század, 36 géppuskás szakasz, 14 aknavető raj, 14 árkász szakasz, 7 karhatalmi kerékpáros század.

- 2 karhatalmi lovas ezred, ezen belül: 4 huszárosztály, 4 lovas géppuskás század, amelyek állnak 8 honvéd lovas szakaszból, 8 csendőr lovas szakaszból és 8 lovas géppuskás szakaszból;

- 1 karhatalmi tüzérosztály, ezen belül: 7 tábori ágyús üteg, 5 lovas ágyús üteg, 1 tarackos üteg, 3 aknavetö-félüteg és 3 légvédelmi-félüteg;

- 3 karhatalmi utász zászlóalj, ezen belül: 6 utászszázad;

- 2 karhatalmi híradó szakasz;

- 1 karhatalmi páncélgépjármüves szakasz;

- 1 karhatalmi gépkocsi oszlop;

- 1 karhatalmi sebesültszállító oszlop;

- 1 karhatalmi egészségügyi oszlop;

- 1 karhatalmi betegszállító vonat;

- 4 karhatalmi ellátó hivatal;

- 6 karhatalmi élelmezési felvevő állomás.

Forrás ! - HIM-HL.HM.eln. 1. 1935/3370. és 5500/1932. Karhatalom kirendelésének, erejének és alkalmazásának szabályozása.

- HIM-HL.HM.eln. 1. 1935/3370. és 5840/1932. Karhatalmi intézkedések helyesbítése.

III.sz. melléklet.

A katonai karhatalmi harcoló állomány létszáma, fegyverzete és lőszerjavadalmazása.

\section{LÉTSZÁM ÉS FEGYVERZET}

Tiszt
Legénység
Összesen
puska
géppuska és golyószóró
löveg és aknavető

853 fö
16923 fó
$\mathbf{1 7} 776$ fo

$12200 \mathrm{db}$
$145 \mathrm{db}$
$70 \mathrm{db}$

\section{LÖSZER}

$\begin{array}{lrr}\text { puska } & 140-40 / 80-40 \mathrm{db} \\ \text { golyószóró } & 1600-1600 / 800-800 \mathrm{db} \\ \text { géppuska } & 4500-2500 / 500-500 \mathrm{db} \\ \text { nehézpuska } & \text { Nincs / } & 120-0 \mathrm{db} \\ \text { közepes löveg } & \text { Nincs / } & 8-0 \mathrm{db} \\ \text { könnyü löveg } & 12-0 / & 12-0 \mathrm{db} \\ \text { aknavető } & 21-0 / & 52-0 \mathrm{db} \\ \text { páncéltörö ágyú } & \text { Nincs / } & 60-0 \mathrm{db} \\ \text { kézigránát } & \text { Nincs / } & 2-2 \mathrm{db}\end{array}$

A karhatalmi lőszerjavadalmazást 1942-ben változott, a „/ ”jel előtti adat az 1930-ban meghatározott, a második adat pedig az 1942-ben megadott értéket jelöli.

Forrás ! - HIM-HL HM.eln. 1. 1930/1938. és 8578/1929. Országos karhatalmi készültségbe helyezésről és az országos karhatalmi összevonásról szóló intézkedés. A/II.pont.

- Szabályzat a karhatalmi szolgálat ellátására a Magyar Királyi Honvédség számára. Budapest, 1942, Athenaeum. 104 p. Függelék. 